\title{
Model-Based Evaluation of Hydroelectric Dam's Impact on the Seasonal Variabilities of POC in Coastal Ocean: A Case Study of Three Gorges Project
}

\author{
Dongxing Chen ${ }^{1,2, *}$, Qianqian Liu ${ }^{3}$, Jiexin $\mathrm{Xu}^{4}$ and Kuo Wang ${ }^{1,2}$ \\ 1 School of Marine Sciences, Sun Yat-sen University, Guangzhou 510006, China; wangshi3@mail2.sysu.edu.cn \\ 2 Key Laboratory of Marine Resources and Coastal Engineering in Guangdong Province, \\ Guangzhou 510006, China \\ 3 Cooperative Institute for Great Lakes Research, University of Michigan, Ann Arbor, MI 48108, USA; \\ Liuqianqian0622@gmail.com \\ 4 State Key Laboratory of Tropical Oceanography, South China Sea Institute of Oceanology, Chinese Academy \\ of Sciences, Guangzhou 510301, China; jxxu@scsio.ac.cn \\ * Correspondence: chdxing@mail2.sysu.edu.cn
}

Received: 19 July 2019; Accepted: 10 September 2019; Published: 14 September 2019

\begin{abstract}
Particulate organic carbon (POC) plays an important role in the global carbon cycle. The POC in the Changjiang Estuary and adjacent coastal region of the East China Sea (ECS) is dominated by riverine input and marine production and is significantly influenced by the three gorges project (TGP). A coupled physical-biogeochemical model was used to evaluate TGP's impact on POC. The results demonstrate that TGP regulates the area influenced by diluted water and POC through direct river and sediment discharge and affects the ecosystem. From the early to later TGP construction periods, the surface region with high-POC concentration $(>40 \mu \mathrm{mol} \mathrm{L}-1)$ decreases by $20.5 \%$ in area and $11.5 \%$ in concentration. Meanwhile, POC in the whole water column decreases from 19.5 to $17.8 \mu \mathrm{mol} \mathrm{L}^{-1}$. By contrast, the concentrations of chlorophyll-a (Chl-a) and related nutrients increase. A three end-member mixing model based on quasi-conservative temperature and salinity is used to quantify relative contributions of different water sources to POC in our research area. We also estimate the biological POC production by the difference between the physical-biogeochemical model predicted POC and three end-member model mixing POC. The result demonstrate that under the regulation of TGP in the later period, the decrease of sediment load increases water transparency, which favors photosynthesis and oceanic biological produced POC. In addition, over $70 \%$ of the areas have $\mathrm{C} / \mathrm{Chl}-a>200$ and high $\mathrm{C} / \mathrm{N}$ ratios, which are circumstantial evidences that organic detritus and terrestrial input sources still dominate in the Changjiang Estuary and adjacent coastal ECS but are influenced by TGP's regulation.
\end{abstract}

Keywords: physical-biogeochemical model; POC; Chl- $a$; nutrients; East China Sea

\section{Introduction}

The particulate organic carbon (POC), although a small proportion of the total carbon [1,2], is an important component of the "biological pump," which results in the capture and storage of carbon that sinks into the deep ocean [3-6]. Organic carbon in the ocean mainly originates form terrestrial systems (transport via rivers) and oceanic production. It has been reported that $\sim 0.4 \mathrm{Gt}\left(1 \mathrm{Gt}=10^{9} \mathrm{t}\right.$ ) POC from the terrestrial ecosystem are discharged into oceans via rivers each year [7]. Biological productivity of phytoplankton is another important source of POC. Therefore, POC concentration can be closely correlated with the chlorophyll- $a(\mathrm{Chl}-a)$ concentration. For example, the C/Chl- $a$ ratio is often used to analyze the biological activity, which is high in the coastal ocean [8], especially in shallow 
waters [9]. Upwelling transports nutrients from the sediment to the euphotic layer as supply for the POC production [10]. In the coastal region, POC is dominated by riverine input [11,12]. The effect of typhoon-induced upwelling on the POC in the East China Sea (ECS) has been investigated in several studies. The results showed that POC usually increases a few days after typhoon passage $[13,14]$ due to sediment resuspension and the growth of phytoplankton $[15,16]$.

As one of the greatest water conservancy projects in the world, the three gorges project (TGP) has a great influence on the coastal region of the ECS, especially on the region around the Changjiang Estuary $[17,18]$, which connects the biggest river of mainland China with the ECS. Therefore, it is important to study the ecosystem of the Changjiang Estuary by analyzing the POC under the influence of TGP. Liu [19] reported that TGP influences the POC in the ECS in the early TGP period by affecting the nonliving part and the POC concentration gradually decreases from Changjiang Estuary to the outer shelf. Chen [20] suggested that TGP reduces the outflow of the Changjiang River and therefore influences the nutrient supply and decreases the POC in the middle TGP period. By studying the POC concentration and phytoplankton community structure in the ECS before and after TGP water storage, Jiao [21] found that TGP significantly changed the microbial community structure in the ECS. In addition, TGP significantly affects sediment discharge into ECS. The closure of TGP caused not only a dramatic drop in the sediment discharge [17,22,23], but also the erosion of the Changjiang River Delta [24]. It also regulates the seasonal variation of the sediment supply $[25,26]$.

The research on POC has been developing, from simply investigating its distribution and concentration to the flux research, component analysis, and so on. Numerical modeling is one of an advanced method that helps scientists to understand the biogeochemical response from the river to the ocean, overcoming the spatial and temporal resolution limitations of field observations. For example, Chen and Wang [27] built a simple box model to estimate the carbon and nutrient flux from the Changjiang River to the ECS; an biogeochemical model was designed to discuss the largest hypoxia ever recorded off the Changjiang Estuary [28]; and a coupled physical-ecological carbon cycle model was developed by Luo et al. [29] to study the sink and source of carbon dioxide air-sea interaction.

In the coastal region, POC from terrestrial input and biological self-production dynamically changes during different seasons [30]. In addition, satellite data revealed that the surface POC decreases, while Chl- $a$ increases during long-term variation [31]. However, the response of POC to different TGP periods and a quantitative estimate of POC sources are still unexplored. This motivates further research into investigation of 1) why Chl- $a$ and POC variations present opposite trends in the coastal region, 2) whether these opposite trends are related to TGP's regulation of water and sediment discharge, and 3) how the terrestrial input and ocean-produced POC change during different periods.

In this study, we used a 3D-coupled physical-biogeochemical model, that is, the Carbon, Silicate, Nitrogen Ecosystem Model (CoSiNE) [32], coupled with the Regional Ocean Modeling System (ROMS), to investigate the impact of TGP on POC and other biochemical variables through regulating the water flux and sediment discharge. In addition, a three end-member mixing model was built to assess the potential POC sources and variation. As a case study, our method can be applied in exploring ecosystems in other similar coastal areas around the world that are influenced by dams from upstream rivers, for example, along the Pacific coast of Mexico, the major rivers of Santiago River and Fuerte River were dammed and affected the estuaries' ecosystem [33]. The model configuration is described in Section 2. The model results and discussion, including the long-term POC variation, spatial distribution, and comparison of related variables are provided in Section 3. A brief summary is given in Section 4 .

\section{Model and Data}

\subsection{Physical Model}

The physical simulation is performed by ROMS [34,35], which is a free-surface, terrain-following, primitive equations ocean model that has been widely used for coastal oceans [36-39]. Following Zhou et al.'s approach [40], the computational domain in this study ranges from $23.5^{\circ} \mathrm{N}$ to $41^{\circ} \mathrm{N}$ and 
$117.5^{\circ} \mathrm{E}$ to $132^{\circ} \mathrm{E}$, covering the Bohai, Yellow, and East China seas and parts of the northeastern Pacific and Japan seas (Figure 1). The model has a $1 / 24^{\circ}$ horizontal resolution, with $\sim 3.5 \mathrm{~km}$ in the north and $\sim 4.2 \mathrm{~km}$ in the south. It has 30 terrain-following vertical layers in a s-coordinate system, with a $1500 \mathrm{~m}$ cutoff to reduce the spin-up time. The model's external time step is $92 \mathrm{~s}$.

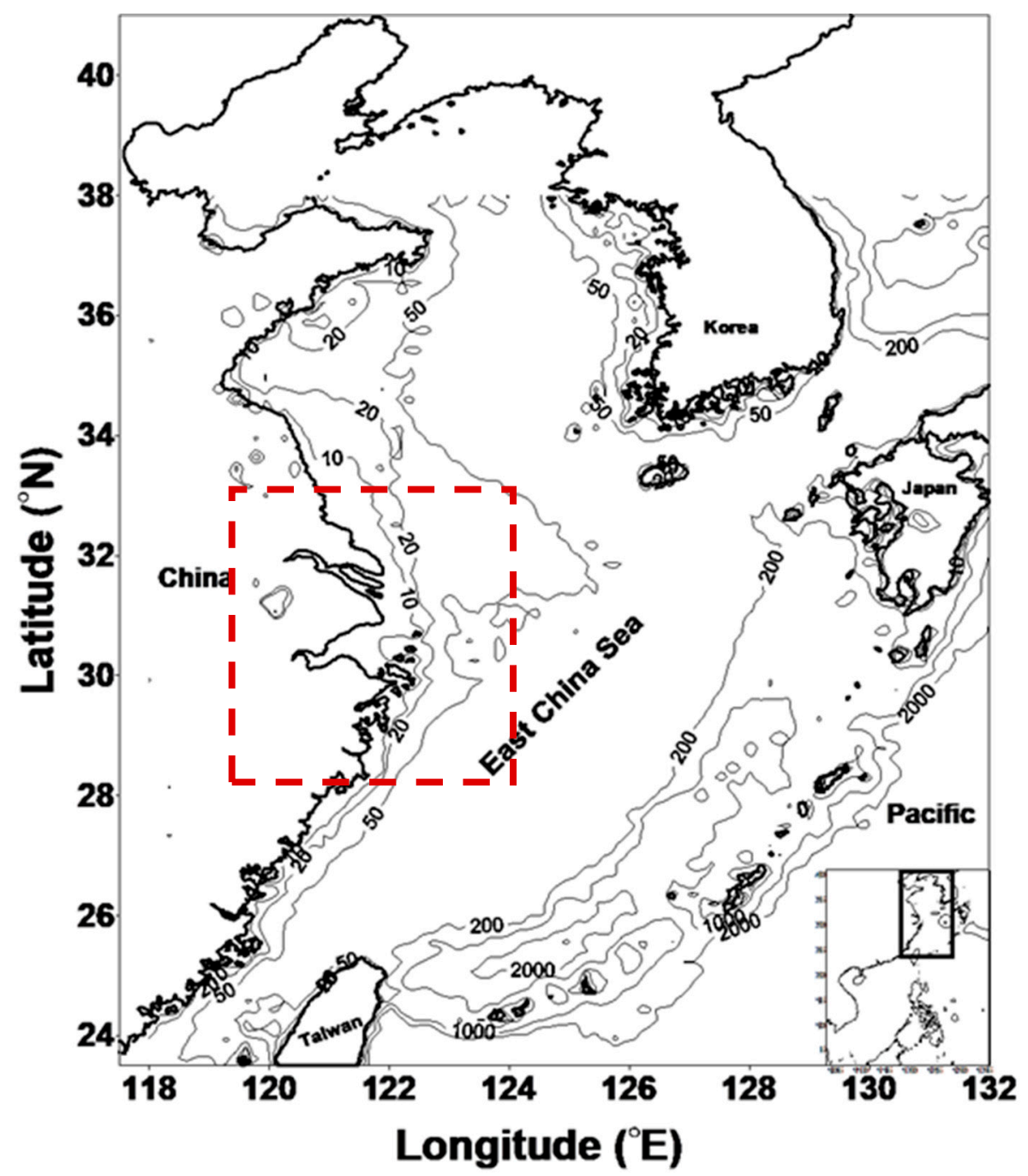

Figure 1. Bathymetry of the modeled area. The red dashed box represents our research area.

The model has three open boundaries, that is, the eastern, southern, and northeastern boundaries (Figure 1). The M2 tidal ellipses and elevation parameters from the TPXO7 model [41] are applied to the open boundaries. Seven major rivers, including the Changjiang, Huanghe, Liaohe, Yalvjiang, Hanjiang, Qiantangjiang, and Minjiang rivers, are included in the model as point sources with monthly averaged discharge provided at the river mouths. The monthly averaged water flux for Changjiang diluted water (CDW) was obtained from data at the Datong Station [42], while the data for other rivers were taken from Chang and Isobe [43] and Zhou et al. [40]. Other physical settings are as follows: the surface wind stress was calculated using the equation of Large and Pond [44]; the radiations and surface freshwater were derived from national centers for environmental prediction (NCEP) reanalysis data [45], while the heat flux was calculated from the prescribed shortwave/longwave radiations; and the air-sea momentum flux was obtained from the blended sea winds dataset, which provides $0.25^{\circ} \times 0.25^{\circ}$ gridded ocean vector winds [46]. Data interpolation has been processed to uniform the different spatial and temporal resolutions. 


\subsection{Ecosystem Model}

The Carbon, Silicate, and Nitrogen Ecosystem (CoSiNE) model [32,47] consists of 13 variables, including nitrate, phosphate, silicate, ammonium, carbon dioxide, oxygen, alkalinity, two phytoplankton groups, two zooplanktons, and two detritus pools (Figure 2). The variable P1 stands for small phytoplankton (diameter $<5 \mu \mathrm{m}$ ), whose biomass is regulated by micro-grazers (Z1) and production is highly remineralized $[48,49]$. The variable P2 represents diatoms (diameter $>5 \mu \mathrm{m}$ ), which usually has a higher biomass and grows fast under optimal nutrient conditions [50]. The variable $Z 2$ represents mesozooplankton that grazes on diatoms and preys on Z1 [51]. Fecal pellets produced by Z1 and Z2 flow into two detritus pools and balance the nutrient supply. A portion of the detritus-nitrogen (DN) and detritus-silicon (DSi) escapes the system through sinking, while other portions are recycled by remineralization or dissolution.

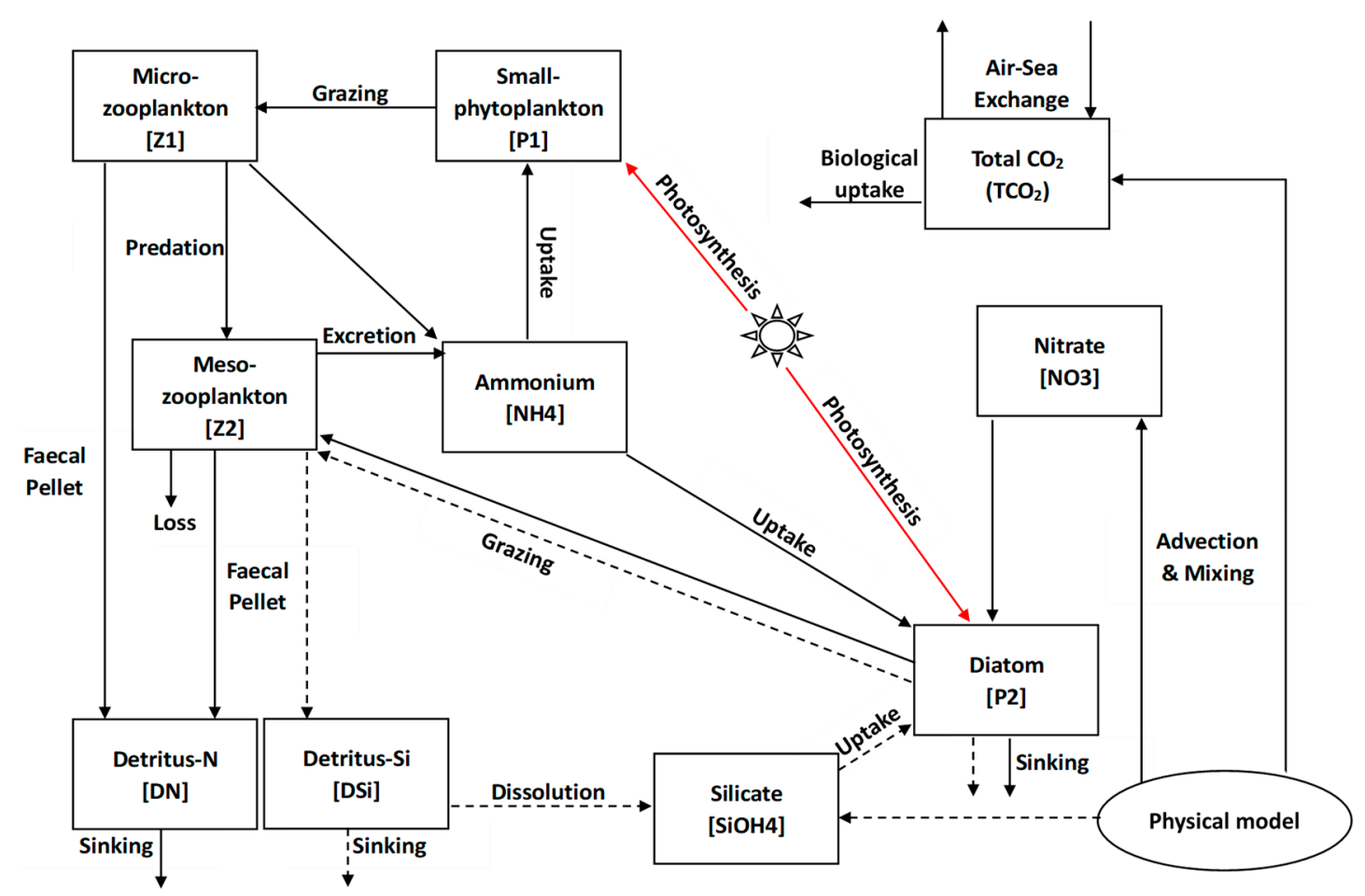

Figure 2. Flowchart of the CoSiNE model in the euphotic layer. Solid lines represent the flow of nitrogen, while dashed lines represent the flow of silicon.

The CoSiNE is a nitrogen-based model. To link carbon with nitrogen, a $\mathrm{C} / \mathrm{N}$ molar ratio of 7.3 [52] is used, that combines the consumption and remineralization of assimilated nutrients based on nitrogen changes in the water column with Redfield stoichiometric ratios [53]. The POC part is the combination of the state variables S2, Z1, Z2, DN, and DSi with the advection, diffusion, and vertical mixing controlled by the physical model. Detailed descriptions and parametric settings are available in Xiu and Chai [54] and Zhou et al. [28]. The riverine input of the POC setting refers to Ludwig et al. [55]:

$$
\begin{gathered}
\text { POC } \%=-0.16 \log \left(C_{T s S}\right)^{3}+2.83 \log \left(C_{T s S}\right)^{2}-13.6 \log \left(C_{T s s}\right)+20.3 \\
C_{P O C}=C_{T s S} \times \text { POC } \%
\end{gathered}
$$

where $C_{T s s}$ represents the sediment concentration in the river, which was obtained from the River sediment bulletin of China [56], and $C_{P O C}$ is the riverine POC input. The ecosystem model was initialized from the temperature, salinity, nutrients, and open boundary conditions from the Pacific-CoSiNE model [57]. 
The model initialized with a climatology run was derived from multiyear observations [40] and ran for 10 years to reach an equilibrium state. Temperature, salinity, and currents from the December of the last year were extracted as the initial conditions for the running in our research area, from January 1990 to December 2008. The seasonal averages (Spring: March to May; Summer: June to August; Autumn: September to November; Winter: December to February) from 1994 were extracted for analysis. Our research area is a $5^{\circ} \times 5^{\circ}$ region $\left(28^{\circ}-33^{\circ} \mathrm{N}, 120^{\circ}-125^{\circ} \mathrm{E}\right)$, which ranges from the Changjiang Estuary to the $50 \mathrm{~m}$ isobaths of the ECS.

\subsection{Model Validation}

Reanalysis data from the Japan Coastal Ocean Predictability Experiment (JCOPE) and satellite data from the Moderate Resolution Imaging Spectroradiometer (MODIS) were used to evaluate the model results. The JOCPE data has assembled all available data obtained from satellites, ARGO floats, and ships in an ocean forecast system. This reanalysis data have horizontal high resolution of $1 / 12^{\circ}$, validated and applied in many researches with great performance [58,59]. Data of regional-averaged (in our research area) and monthly-averaged sea surface salinity (SSS) and sea surface temperature (SST) from the JOCPE data and our model results are compared (Figure 3a,b). In the whole TGP period from 1994 to 2008, our model results capture anomalies in some specific years and match well with the reanalysis data, e.g., the interannual variabilities of SSS with low SSS in summer of 1998, which is due to El Niño, 1999, 2002, and 2003, and high SSS in 2000 and 2001. Although reanalysis data values are slightly larger, our model results are consistent with the reanalysis data in the seasonal and interannual variabilities of SSS and SST.
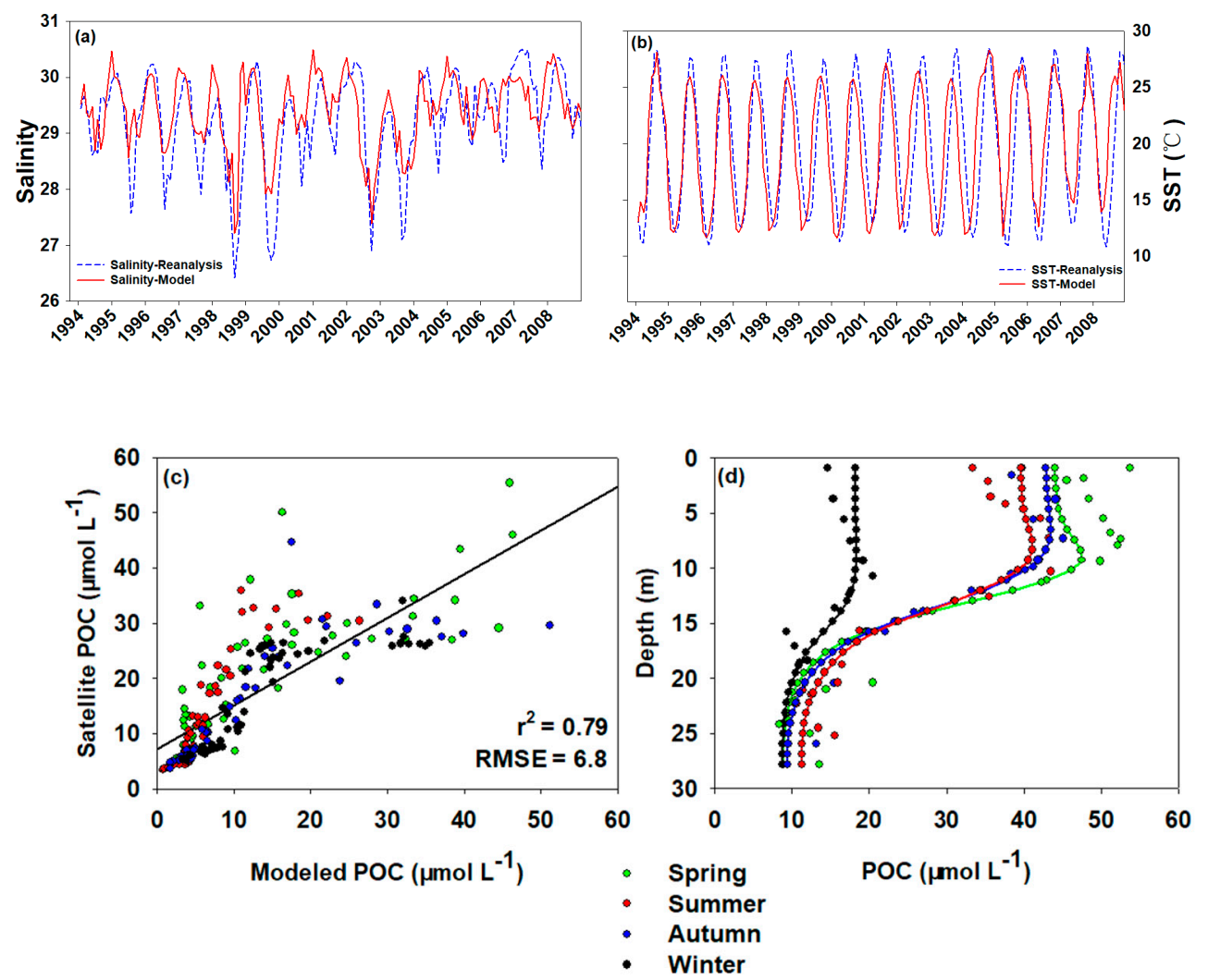

Figure 3. Comparison of reanalysis, satellite, and in situ data with our model results. (a,b) represent long time variation of sea surface salinity and temperature, respectively. (c) indicates the correlation analysis of satellite and modeled data in the surface layer. In (d), the solid lines represent the modeled data, while the colored dots represent in situ data of the vertical distribution. 
The MODIS Level-3 POC with a horizontal resolution of $4 \mathrm{~km}$ from 2002 to 2008 was obtained from National Aeronautics and Space Administration (NASA) and then reprocessed to derive the seasonal mean. We compared the model results with satellite data at the same time and same location and carried out correlation analysis. The correlation coefficient is 0.79 with RMSE reaching 6.8, demonstrating a strong correlation between our model results and the satellite data (Figure 3c). In spring and autumn, the surface POC concentrations are relatively higher and more scattered than in summer and winter, which is consistent with the vertical profile results. In situ data from references and cruises were chosen to evaluate the vertical structures of the modeled POC [60-65]. The model captures vertical POC structures, including the POC increase from surface to subsurface ( 10 m below the surface) and decrease from subsurface to the deep ( $\sim 20 \mathrm{~m}$ below the surface). In addition, the model captures the seasonal change of the vertical structure with much smaller vertical variation in winter than the other seasons, and largest in summer. Overall, the results reasonably reflect the POC variability in an appropriate range.

\section{Results and Discussion}

\subsection{River and Sediment Discharge}

The model results can be divided into three parts according to TGP construction periods: 1) ES-TGP (1994-1997): early period, from the beginning of the three gorges dam construction to the damming of the Changjiang River; 2) MS-TGP (1998-2003): middle period, from the filling of TGP reservoir to the beginning of the power generation; and 3) LS-TGP (2004-2008): late period, from the time of water level raising and full power generation to the end of the construction. The river input and sediment discharge are greatly influenced by different periods of TGP (Figure 4). During the whole TGP period, the average water flux is $28.93 \times 10^{3} \mathrm{~m}^{3} \mathrm{~s}^{-1}$ and the average sediment discharge is $2.54 \mathrm{Gt} \mathrm{a}^{-1}$. In the ES-TGP, i.e., the preparatory period [66,67], the river flux, and sediment discharge are not affected by the construction of TGP, with the water discharge of $29.80 \times 10^{3} \mathrm{~m}^{3} \mathrm{~s}^{-1}, 3 \%$ higher than the average value, and sediment discharge of $3.16 \mathrm{Gt} \mathrm{a}^{-1}, 19.6 \%$ higher than the average value. During the MS-TGP, river discharge significantly increases, reaching $31.07 \times 10^{3} \mathrm{~m}^{3} \mathrm{~s}^{-1}$, almost $7.5 \%$ higher than the whole TGP average. The sediment discharge is $3.04 \mathrm{Gt} \mathrm{a}^{-1}$ in this period, $16.4 \%$ above the average. This is due to the catastrophic flood caused by a strong El Niño climatic anomaly during that time [68].

The water flux slightly decreased in the LS-TGP, with an average of $25.68 \times 10^{3} \mathrm{~m}^{3} \mathrm{~s}^{-1}$, that is, $11.25 \%$ below average. The sediment discharge reached $1.43 \mathrm{Gt} \mathrm{a}^{-1}$ with a change rate of $-55 \%$ compared with the ES-TGP. The main reasons for the dramatic change are the decrease in the water storage and sediment in the reservoir; the extent of decline is even larger when compared with historical data $[17,25,69]$. In addition, TGP reservoir increased water levels to $175 \mathrm{~m}$, resulting in the impoundment of the reservoir reaching 39.3 billion $\mathrm{m}^{3}$ and the impoundment and discharge of the dam seasonally $[70,71]$, which is the principle factor controlling the seasonal variation of water flux in Changjiang Estuary and adjacent coastal ECS. Our model results analysis is based on the tremendous differences in the riverine water flux and sediment discharge from the CDW under TGP regulation. 


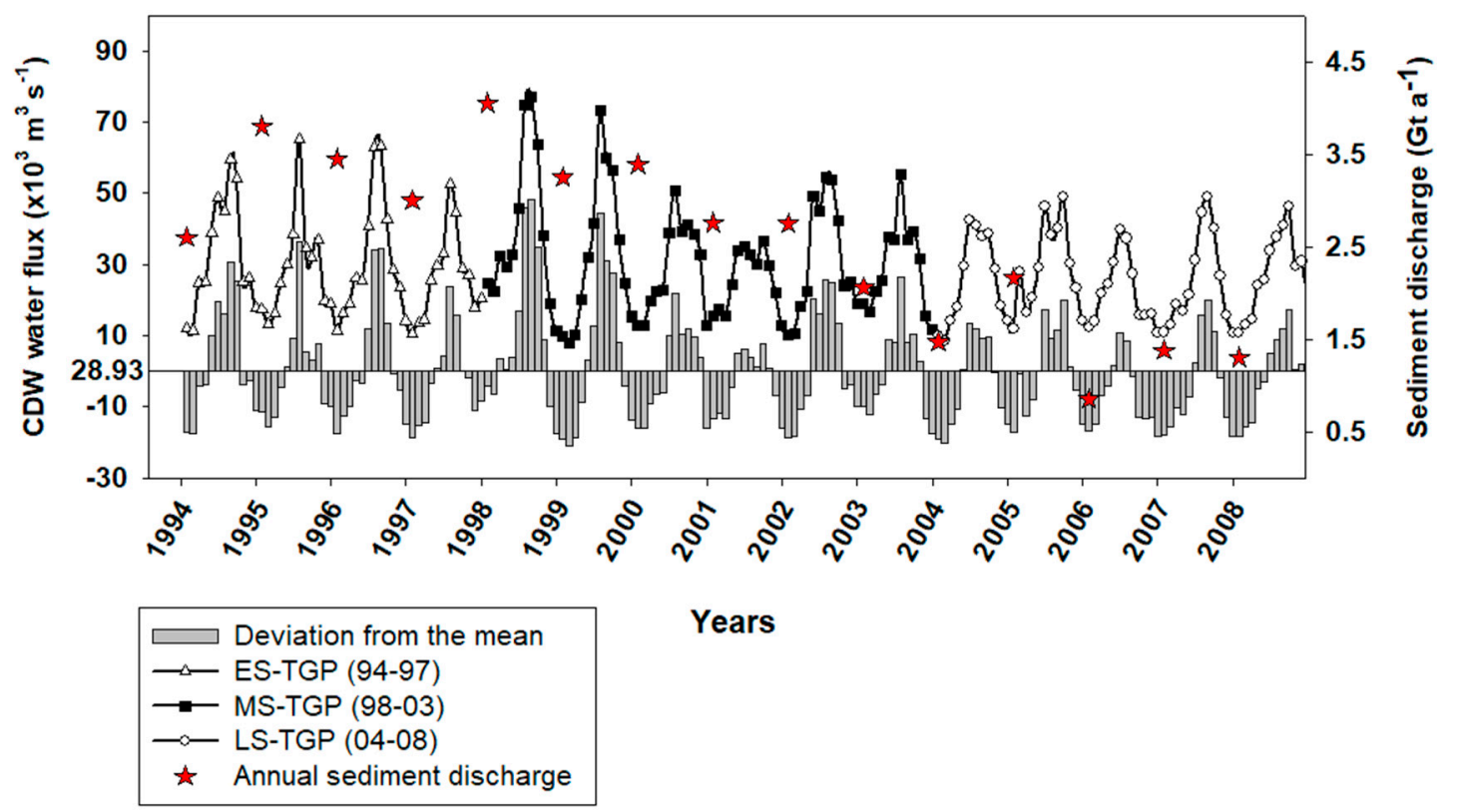

Figure 4. Monthly values of CDW flux and sediment discharge during the three TGP construction periods. The triangular, square, and rounded lines represent water flux in the ES-TGP, MS-TGP, and LS-TGP, respectively. Histogram represents deviation values from the mean diluted water flux during the whole TGP period. The red star represents the annual sediment discharge to the Changjiang Estuary. The data were obtained from the Datong hydrological station.

\subsection{Seasonal Distribution}

To examine the impact of the river flux and sediment discharge on the seasonal variability of the coastal water mass, the seasonally averaged surface salinity distribution in the Changjiang Estuary and adjacent ECS during different TGP periods is shown in Figure 5. Because the dam regulates river flux seasonally, from the ES-TGP to LS-TGP, the $30 \mathrm{psu}$ isohaline retreats from $122.5^{\circ} \mathrm{N}$ to $122^{\circ} \mathrm{N}$ in summer and autumn (wet season) and moves forward from $121.5^{\circ} \mathrm{N}$ to $122^{\circ} \mathrm{N}$ in winter and spring (dry season), which indicates the notable shrinking of the area influenced by diluted water in the wet season and expansion in the dry season. The area with low-salinity $(<30 \mathrm{psu})$ water decreases by $14.7 \%$ in the wet season, while it increases by $6.5 \%$ in the dry season.

Figure 6 shows the horizontal distribution of the POC area. According to our simulation, the maximum POC concentration appears around the high turbidity area, around $122^{\circ} \mathrm{E}$ close to the Changjiang Estuary, especially in summer in the ES-TGP period. The interaction of saline and diluted water and wind- and wave-induced entrainment cause intensive sediment resuspension in shallow waters [72-74], and the intensive resuspension generates high-POC area (POC concentration $>40 \mu \mathrm{mol} \mathrm{L}^{-1}$ ) in the estuary and adjacent coastal ECS.

The POC pattern in the research area also shows strong seasonal variations, with the highest average concentration of $27.7 \mu \mathrm{mol} \mathrm{L}{ }^{-1}$ in summer in the MS-TGP and lowest of $13.7 \mu \mathrm{mol} \mathrm{L}^{-1}$ in winter in the LS-TGP (Figure 6). At approximately $30.5^{\circ} \mathrm{N}$ and $122^{\circ} \mathrm{E}$ in the Changiiang Estuary, the high-POC area reaches a maximum in summer, followed by spring and autumn, and a minimum in winter. The seasonal variability of POC is driven by a combination of several factors, including turbidity, daylength, water temperature, and CDW freshwater and sediment discharge. 


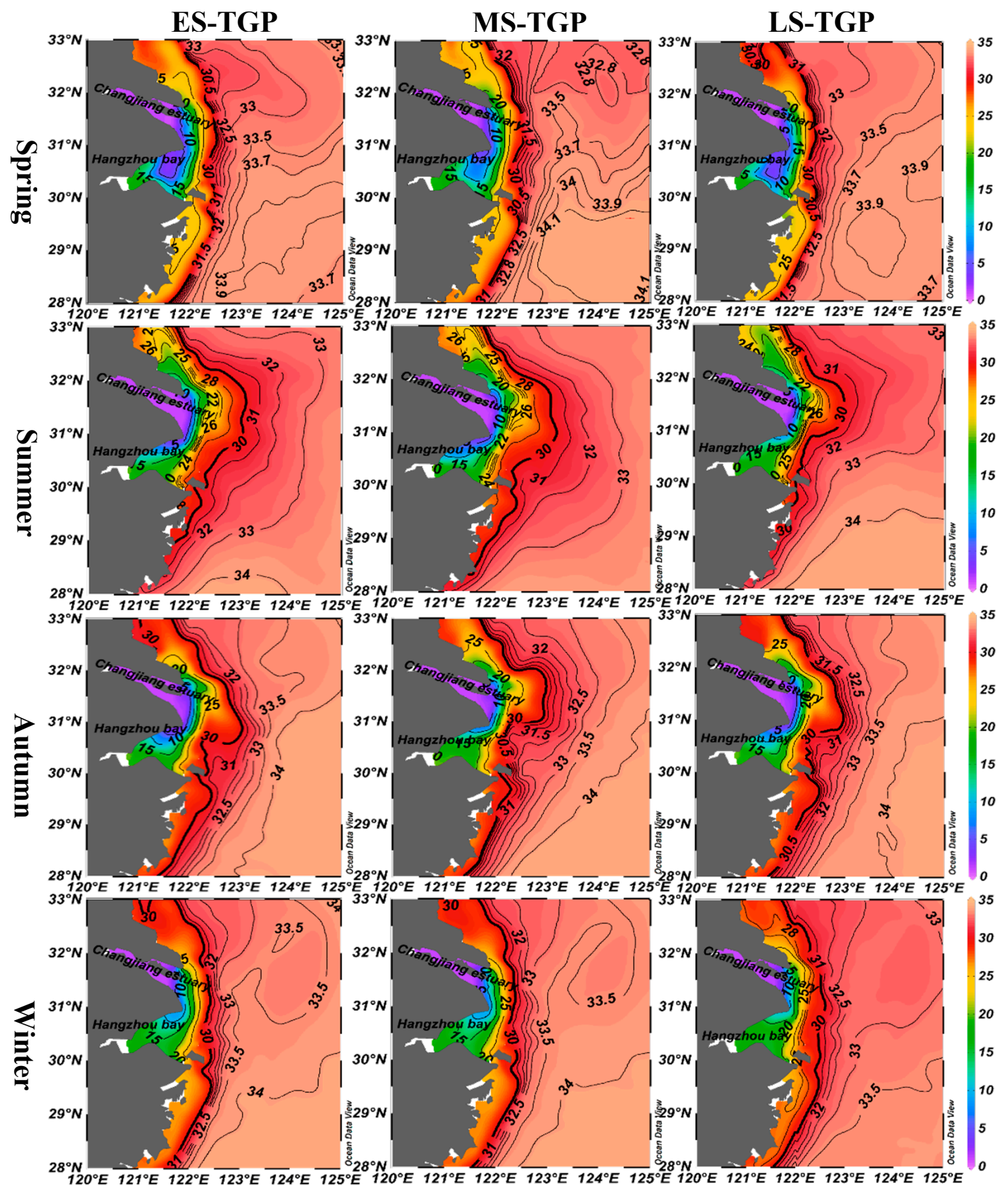

Figure 5. Seasonal average of the modeled horizontal distribution of the surface salinity around the Changjiang Estuary and adjacent ECS during different TGP periods. The bold curve represents a salinity of 30 .

Even though the enormous CDW tongue can even reach Jeju Island [75], the POC concentration rapidly decreases from the coastal area to the open ocean. That is because the sediment resuspension in the open ocean is constrained by the water depth and water column stratification, which also limits the nutrient supply required for phytoplankton production $[76,77]$. The weak sediment resuspension and nutrient limitations, hence reduced POC from biological productivity, together causing the minimum POC value in the offshore region close to the continental shelf of the ECS. 
In spring, the light availability to phytoplankton increases because of the reduction in mixing-induced turbidity and increase in daylength. The water temperature increases and large CDW discharge brings more nutrients to the study region. All these conditions favor phytoplankton biomass and lead to an increase in the oceanic POC production. In contrast, the POC concentration is relatively lower in autumn and winter (Figure 6), which is due to different mechanisms. The low concentration in autumn is due to the depletion of nutrients by summer bloom and the gradually suppressed CDW discharge. In winter, it is attributed to the (a) low oceanic POC production caused by intense turbidity blocks photosynthesis; (b) reduction in riverine nutrients, sediment, and POC input; and c) oligotrophic open sea water invasion.

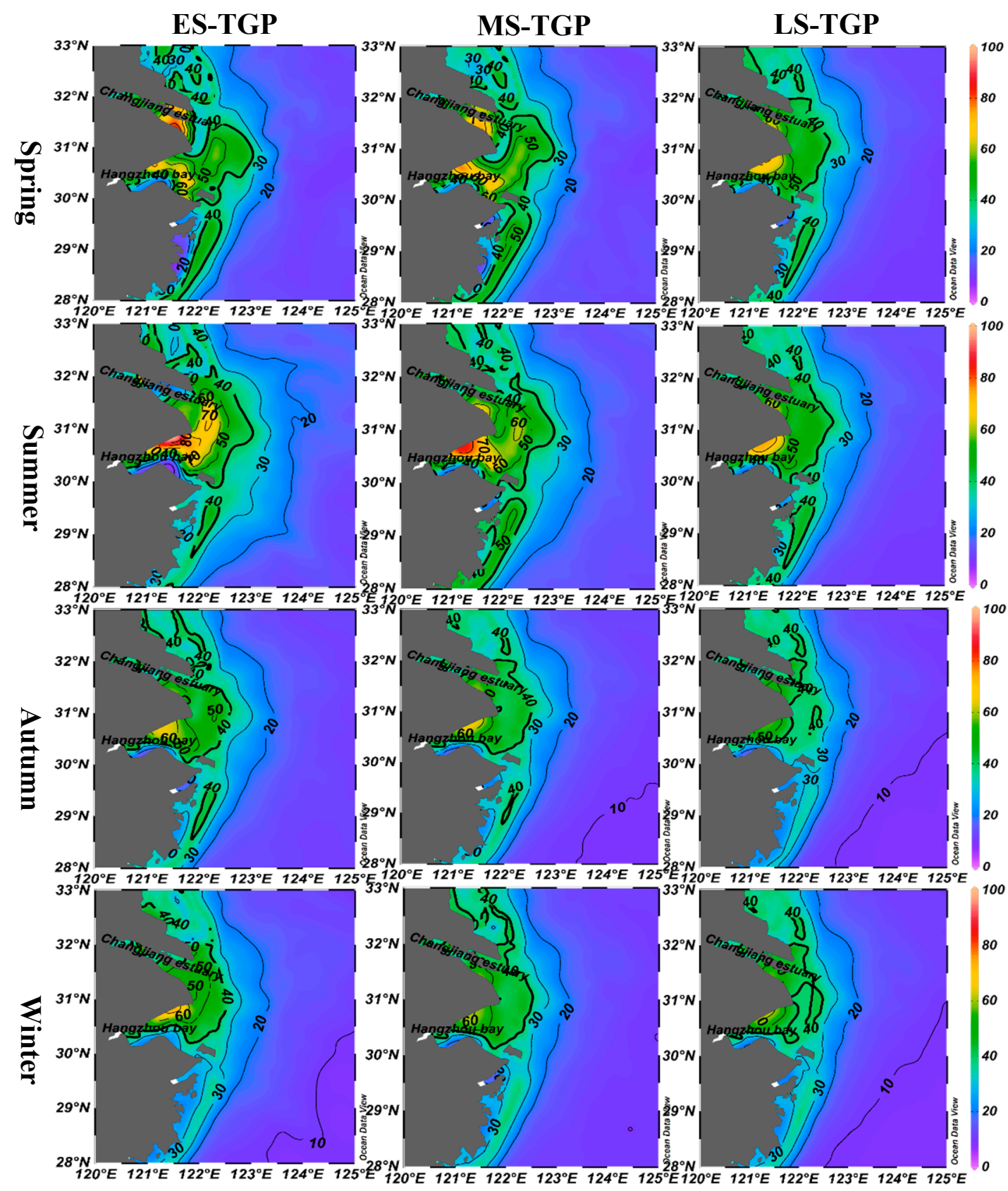

Figure 6. Seasonal surface distribution of the POC around the Changjiang Estuary and adjacent ECS during the TGP periods based on the model simulation results. The bold curve represents a POC value of $40 \mu \mathrm{mol} \mathrm{L}{ }^{-1}$. 
Besides the seasonal fluctuation, our model results show the change of POC during different TGP states, with the average POC during the LS-TGP smaller than during the ES- and MS-TGP, obviously. In the long term, the impoundment of TGP decreases the suspended matter from the Changjiang River to the Changjiang Estuary and its adjacent coastal area, and thus the POC concentration along the coast decreases $[17,23]$; In the ES-TGP, the high-POC area around the Changjiang Estuary is $\sim 7468 \mathrm{~km}^{2}$ in spring, with an average concentration of $67.2 \mu \mathrm{mol} \mathrm{L}^{-1}$. In the LS-TGP, this region shrinks to $5936 \mathrm{~km}^{2}$, with an average concentration of $59.6 \mu \mathrm{mol} \mathrm{L}-1$, reflecting a $20.5 \%$ decrease in area and $11.5 \%$ decrease in concentration. The $40 \mu \mathrm{mol} \mathrm{L}^{-1}$ POC isoline moves approximately half a degree in longitude landward than ES-TGP, which is consistent with previous research [78,79].

\subsection{POC and Related Variables}

In addition to the large terrigenous POC input, environmental factors, especially Chl- $a$, play an important role in the biological self-production of POC in the ocean. Nitrate $\left(\mathrm{NO}_{3}\right)$ and phosphate $\left(\mathrm{PO}_{4}\right)$ serve as essential nutrients for the POC production during phytoplankton photosynthesis [80] and are also impacted by terrigenous runoff. In this study, we aim to determine if the POC and related biochemical variables in the whole water column have similar variations with the surface ocean during the three periods. The water column data, including $\mathrm{NO}_{3}, \mathrm{PO}_{4}, \mathrm{Chl}-a$, and POC, based on the model results, are shown in Figure 7.

Figure 7 shows slow but steady increases in the $\mathrm{NO}_{3}, \mathrm{PO}_{4}$, and Chl- $a$ during the three TGP periods. From the ES-TGP to LS-TGP, the average $\mathrm{NO}_{3}$ concentration increases from 19.2 to $20.3 \mu \mathrm{mol} \mathrm{L}{ }^{-1}$, and $\mathrm{PO}_{4}$ from 0.81 to $0.92 \mu \mathrm{mol} \mathrm{L}-1$. The $\mathrm{PO}_{4}$ increasing rate is larger than that of $\mathrm{NO}_{3}$. The Chl- $a$ also grows in this region, with an average value increasing from 1.40 to $1.86 \mu \mathrm{mol} \mathrm{L}^{-1}$ in the whole water column. In contrast, the POC trends are inconsistent during different periods. In the ES-TGP, POC slightly increases, with an average value reaching $19.5 \mu \mathrm{mol} \mathrm{L}^{-1}$. In the MS-TGP, it is similar to the value of the ES-TGP $\left(19.9 \mu \mathrm{mol} \mathrm{L}^{-1}\right)$. In the LS-TGP, it dramatically decreases, with an average value of $17.8 \mu \mathrm{mol} \mathrm{L}^{-1}$.

TGP has a stronger impact on the POC than on Chl- $a, \mathrm{NO}_{3}$, and $\mathrm{PO}_{4}$. The rapid drop of POC in the LS-TGP is highly consistent with the period of TGP impoundment. Previous studies indicated that $\sim 60 \%$ silt in the mainstream is trapped in the reservoir region and $\sim 665$ million $\mathrm{m}^{3}$ sediment accumulates during the LS-TGP [25,81], resulting in the decrease of suspended sediment in the Changiiang River. As a result, the sediment concentration decreased from $0.54 \mathrm{~g} \mathrm{~L}^{-1}$ in 1960 s to $0.28 \mathrm{~g} \mathrm{~L}^{-1}$ in 2008 in the Changjiang Estuary [82,83] and the multi-year average particle size decreased from 0.027 to $0.013 \mathrm{~mm}$ [84]. The weakened water flux and sediment discharge caused by TGP affect the hydrodynamic and microbial activities in the study region. Together with intensifying human activities, this influences the long-term seasonal variability of the nutrient load in the Changjiang Estuary and adjacent coastal ECS. For example, in the wet season with a weakened seasonal fluctuation caused by TGP regulation, the $\mathrm{PO}_{4}$ range increases from $0.70-1.07 \mu \mathrm{mol} \mathrm{L} \mathrm{L}^{-1}$ in the ES-TGP and from $0.79-1.12 \mu \mathrm{mol} \mathrm{L}^{-1}$ in the LS-TGP. The model results demonstrate that the river and sediment discharges affect the POC and related biochemical variables. 


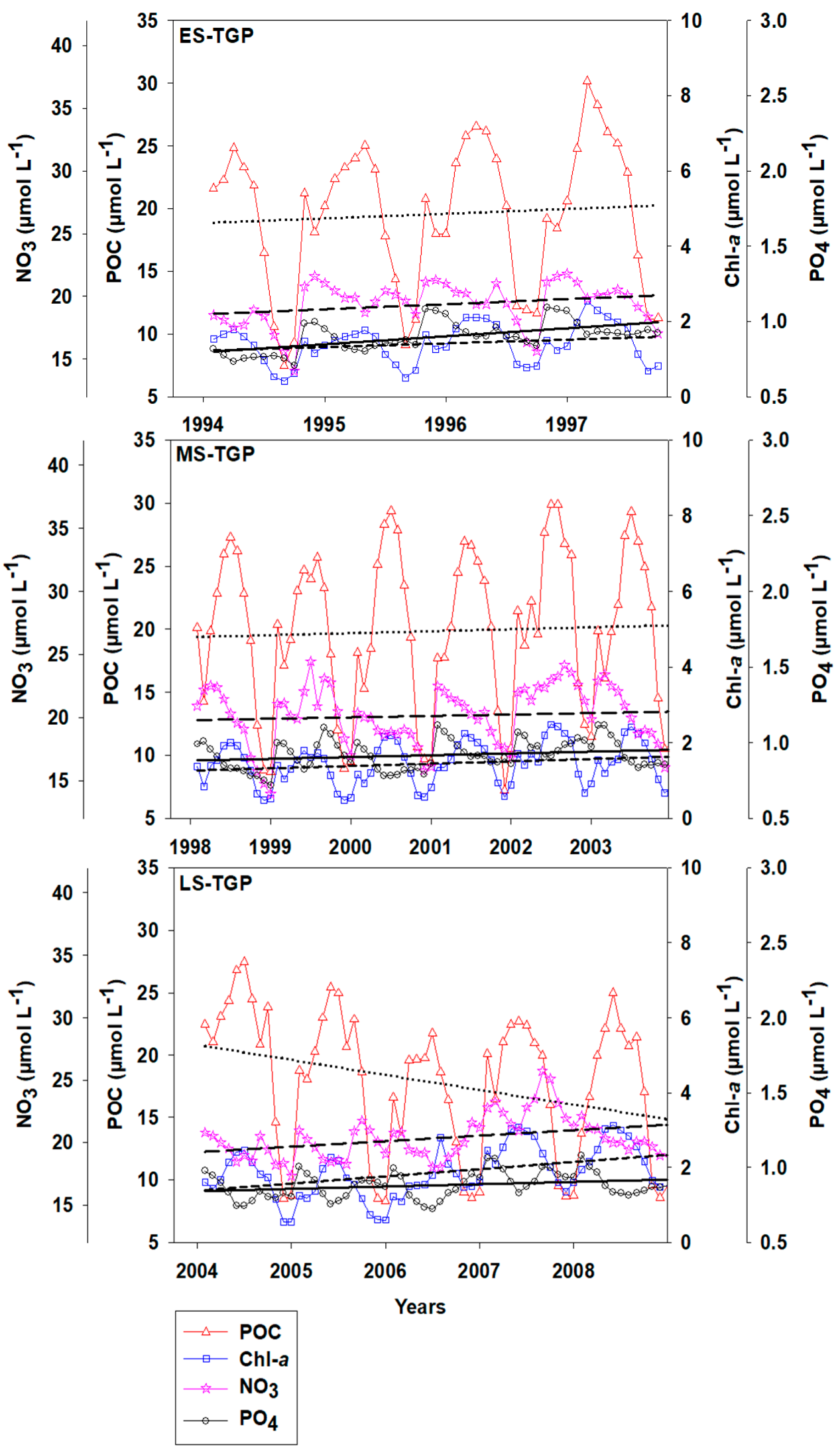

Figure 7. Long-time series variation of the modeled POC (red triangles)/Chl- $a$ (blue squares) $/ \mathrm{NO}_{3}$ (pink stars) $/ \mathrm{PO}_{4}$ (black circles) during the three TGP periods. The dotted, long dashed, short dashed, and solid lines represent the $\mathrm{POC}, \mathrm{Chl}-a, \mathrm{NO}_{3}$, and $\mathrm{PO}_{4}$ trendlines, respectively. 


\subsection{Three End-Member Mixing Model}

In the section above, we qualitatively discussed the influences of the Changjiang water flux and sediment discharge on the POC and related biochemical variables. To quantify the effects, a three end-member mixing model based on quasi-conservative temperature and salinity was built for the research area. Previous studies demonstrated that the potential temperature stays conservative and the influence of surface heating is negligible compared with the mixing effect $[85,86]$, and the model has been validated and performed well in our research area $[87,88]$. The model is governed by the equations [87,89]:

$$
\begin{gathered}
\mathrm{t} 1 \times \mathrm{f} 1+\mathrm{t} 2 \times \mathrm{f} 2+\mathrm{t} 3 \times \mathrm{f} 3=\mathrm{T} \\
\mathrm{s} 1 \times \mathrm{f} 1+\mathrm{s} 2 \times \mathrm{f} 2+\mathrm{s} 3 \times \mathrm{f} 3=\mathrm{S} \\
\mathrm{f} 1+\mathrm{f} 2+\mathrm{f} 3=1
\end{gathered}
$$

where $\mathrm{T}$ and $\mathrm{S}$ represent the potential temperature and salinity from ROMS, respectively; $\mathrm{f} 1$, $\mathrm{f} 2$, and $\mathrm{f} 3$ represent the fractions of diluted water (DW), offshore surface water (OSW), and offshore bottom water $(\mathrm{OBW})$, respectively; $\mathrm{t} 1, \mathrm{t} 2$, and $\mathrm{t} 3$ represent the corresponding temperatures; and $\mathrm{s} 1, \mathrm{~s} 2$, and $\mathrm{s} 3$ are the corresponding salinities of each end-member (Table 1).

Table 1. Example of the temperature $\left(\mathrm{t},{ }^{\circ} \mathrm{C}\right)$, salinity $(\mathrm{s})$, and POC $\left(\mathrm{p}, \mu \mathrm{mol} \mathrm{L}{ }^{-1}\right)$ for the end-members of DW, OSW, and OBW in the ES-TGP used in the three end-member mixing model.

\begin{tabular}{llll}
\hline $\begin{array}{l}\text { Season } \\
\text { Ends }\end{array}$ & $\begin{array}{l}\text { t1/s1/p1 } \\
\text { DW }\end{array}$ & $\begin{array}{l}\text { t2/s2/p2 } \\
\text { OSW }\end{array}$ & $\begin{array}{l}\text { t3/s3/p3 } \\
\text { OBW }\end{array}$ \\
\hline Spring & $13.4 / 0.8 / 58.5$ & $23.8 / 20.1 / 47.7$ & $15.9 / 32.2 / 34.3$ \\
Summer & $26.8 / 0.6 / 56.1$ & $29.7 / 28.1 / 48.1$ & $24.1 / 31.0 / 30.8$ \\
Autumn & $20.9 / 0.6 / 49.9$ & $24.2 / 28.3 / 42.4$ & $19.5 / 31.6 / 31.5$ \\
Winter & $10.3 / 0.9 / 42.8$ & $16.6 / 29.5 / 33.8$ & $12.4 / 32.2 / 28.9$ \\
\hline
\end{tabular}

We calculated the mixing fractions of DW, OSW, and OBW recorded at more than 36,000 data points in the research area. Because of the large number of data points, an arithmetic mean temperature and POC within a salinity of \pm 0.1 in each end-member were adopted to maintain the accuracy. Figure 8 shows the three end-member mixing diagram of the chosen stations with the mixing "envelope" defined by the binary mixing between pairs of end-members. According to Figure 8, in spring, DW, OSW, and OBW are characterized by a low temperature and low salinity, high temperature and middle salinity, and middle temperature and high salinity, respectively. Therefore, DW, OSW, and OBW might be the Changjiang diluted water, Subei alongshore current, and Kuroshio subsurface water, respectively [90,91].

Based on available studies, the water mass in the research area is dominated by DW, OSW, and OBW [92-94]. The mixing fractions of DW, OSW, and OBW from the three end-member model are listed in Table 2. Seasonal variations are particularly pronounced during different TGP periods. In spring, OBW dominates in the research area, especially in the ES-TGP, which occupies more than $50 \%$ of the water mass in the whole water column. In summer, DW prevails over OBW, particularly in the ES-TGP and MS-TGP, with DW proportions reaching $51.7 \%$ and $56.2 \%$, respectively. The proportions of the three water masses stabilize in autumn; none of them dominates in the research area. OBW dominates in winter, especially in the ES- and MS-TGP. However, as shown in Table 2, under the influence of TGP, the proportions of each water mass in four seasons approach each other during the LS-TGP period. 


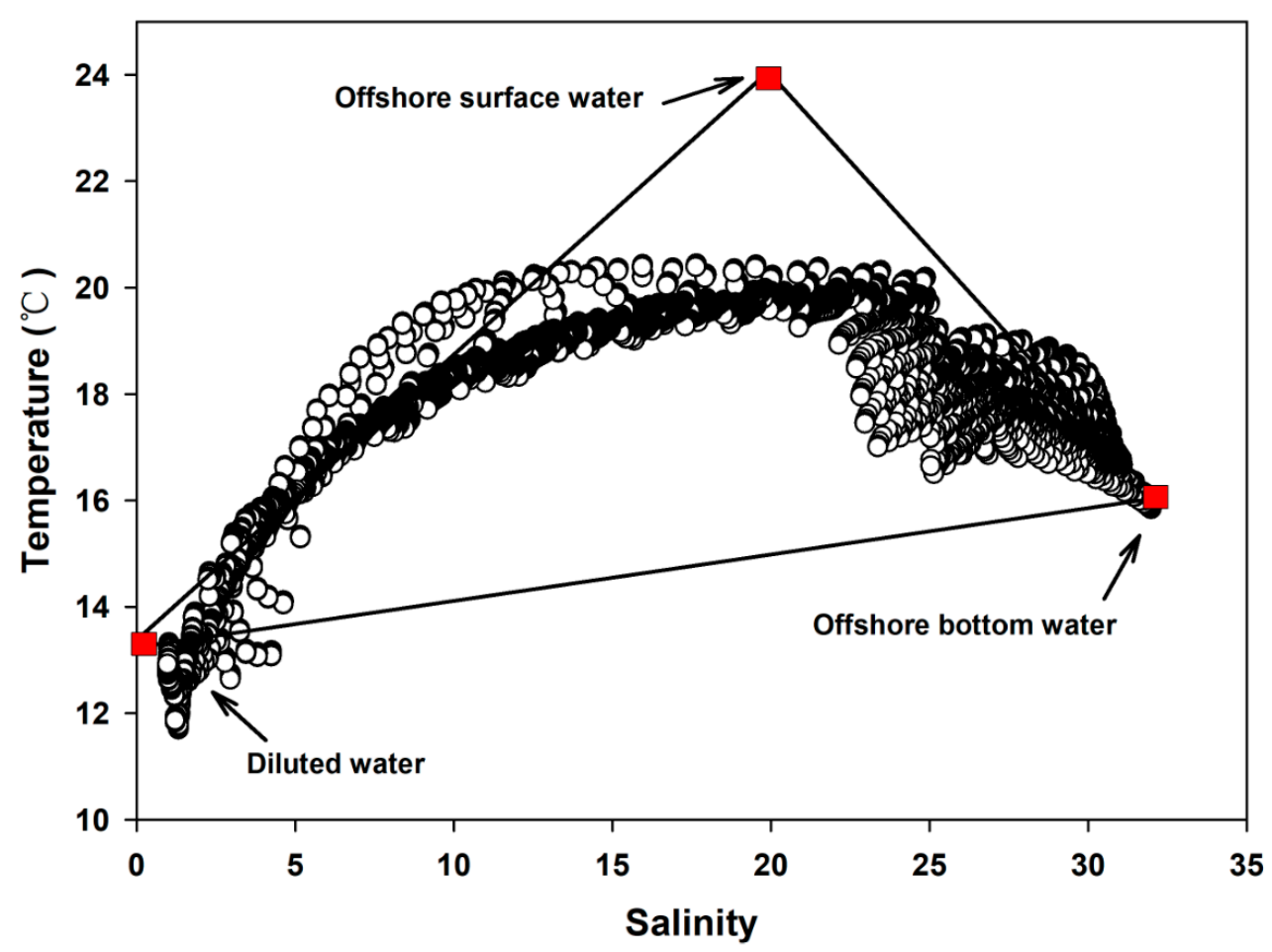

Figure 8. Three end-member mixing model built to distinguish the contribution of potential sources of POC in the research area in the coastal ECS. The graph contains parts of the sample points collected in the ES-TGP in spring; the red squares represent the DW plume (low temperature and low salinity), OSW (high temperature and middle salinity), and OBW (middle temperature and high salinity), respectively.

Table 2. Contribution of the DW, OBW, and OSW in four seasons calculated using the three end-member mixing model in different periods. The bold font indicates that the water mass accounts for $>50 \%$ of the data points in the whole water column.

\begin{tabular}{lllll}
\hline Period & Season & DW\% & OBW\% & OSW\% \\
\hline \multirow{2}{*}{ ES-TGP } & Spring & $33.30 \%$ & $\mathbf{5 1 . 3 0} \%$ & $15.40 \%$ \\
& Summer & $\mathbf{5 1 . 7 0} \%$ & $37.20 \%$ & $11.10 \%$ \\
& Autumn & $37.50 \%$ & $40.80 \%$ & $21.70 \%$ \\
& Winter & $\mathbf{2 6 . 3 0 \%}$ & $\mathbf{6 0 . 4 0 \%}$ & $13.30 \%$ \\
\hline \multirow{2}{*}{ MS-TGP } & Spring & $33.80 \%$ & $43.80 \%$ & $22.40 \%$ \\
& Summer & $\mathbf{5 6 . 2 0} \%$ & $31.50 \%$ & $12.30 \%$ \\
& Autumn & $38.60 \%$ & $42.50 \%$ & $18.90 \%$ \\
& Winter & $25.90 \%$ & $\mathbf{5 3 . 3 0} \%$ & $20.80 \%$ \\
\hline \multirow{7}{*}{ LS-TGP } & Spring & $38.70 \%$ & $49.80 \%$ & $11.50 \%$ \\
& Summer & $45.80 \%$ & $43.50 \%$ & $10.70 \%$ \\
& Autumn & $41.60 \%$ & $35.90 \%$ & $22.50 \%$ \\
& Winter & $34.90 \%$ & $40.00 \%$ & $25.10 \%$ \\
\hline
\end{tabular}

Because each data point has a corresponding POC value, we calculated POC due to the mixing effect $\left(C_{\text {charateristic }}\right.$, Table 1$)$ at the selected $36,000+$ data points (Figure 9$)$ using the mixing fractions $\left(\mathrm{DW} \%, \mathrm{OBW} \%\right.$, and OSW\%) in Table 2 and the characteristic POC values of the DW $\left(C_{D W}\right), \mathrm{OBW}\left(\mathrm{C}_{\mathrm{OBW}}\right)$, and OSW (CosW) end-members, with the following equation:

$$
C_{\text {charateristic }}=C_{D W} \times \mathrm{DW} \%+\mathrm{C}_{\mathrm{OBW}} \times \mathrm{OBW} \%+\mathrm{C}_{\mathrm{OSW}} \times \mathrm{OSW} \%
$$


The preliminary oceanic POC production $\left(C_{\text {bio-effect }}\right)$ is calculated as the difference between ROMS-CoSiNE modeled POC $\left(C_{\text {model }}\right)$ and POC due to the mixing of three end members $\left(C_{\text {charateristic }}\right)$ :

$$
C_{\text {bio-effect }}=C_{\text {model }}-C_{\text {characteristic }}
$$

where a positive and negative $C_{\text {bio-effect }}$ represents the oceanic biological production and consumption, respectively. Figure $9 a-c$ show an example of the surface distribution, while Figure $9 d-f$ represent the bottom distribution of the biological effect in different periods of spring. A strong biological activity can be observed around the estuarine and coastal areas, especially in the region close to the Hangzhou Bay and Changjiang Estuary. The $C_{\text {bio-effect }}$ is mainly positive at the surface but negative at the bottom, indicating biological production at the surface and consumption at the bottom. From ES-TGP to LS-TGP, the decrease in the sediment discharge weakens the turbidity in the coastal ECS; together with the increase in nutrients, this favors photosynthesis and marine production of POC.

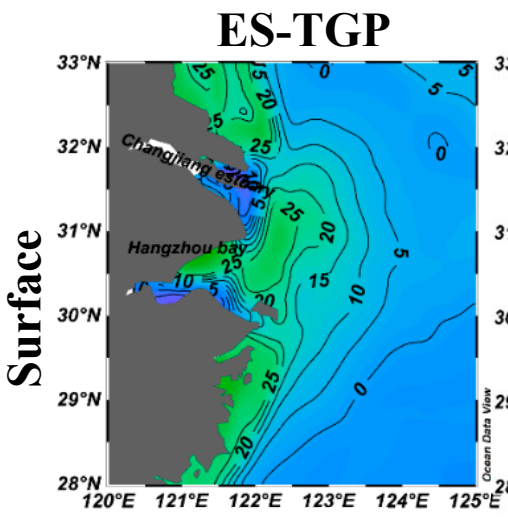

(a)

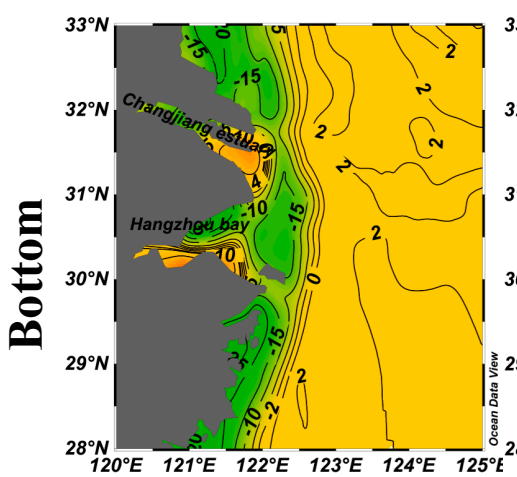

(d)

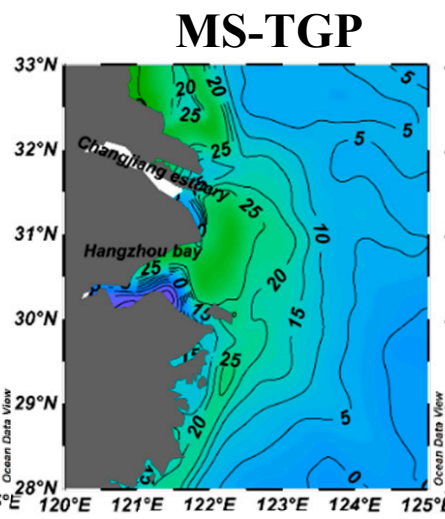

(b)

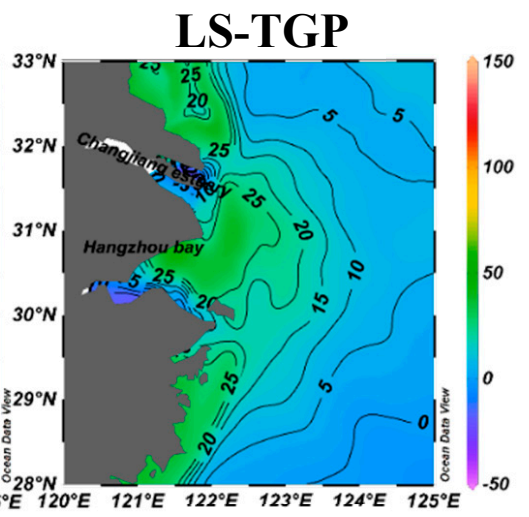

(c)

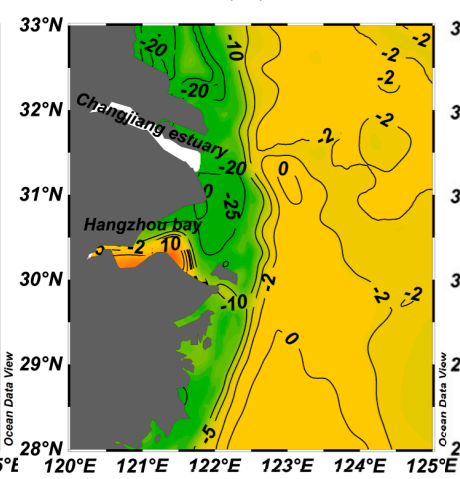

(e)

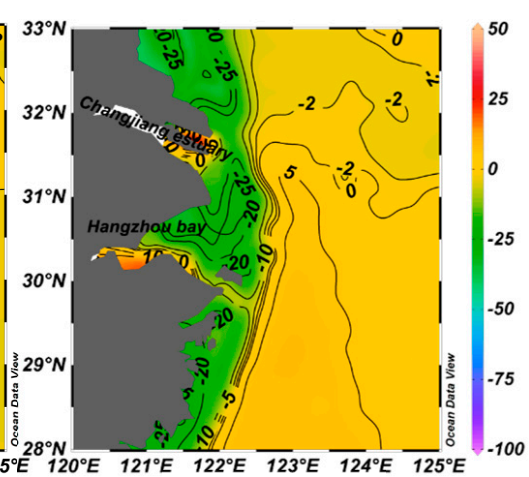

(f)

Figure 9. Spring biological effect of the POC in the Changiiang Estuary and adjacent East China Sea. $(\mathbf{a}-\mathbf{c})$ : Surface effects during ES-TGP, MS-TGP and LS-TGP, respectively; (d-f): Bottom effects during ES-TGP, MS-TGP and LS-TGP, respectively.

Generally, the POC decreases when oligotrophic water mass dominates and vice versa $[95,96]$. Due to the weakly diluted water discharge in the dry season, the OBW from the open ocean, such as the Kuroshio subsurface water, occupies this area [97]. The strong vertical mixing induced by the northeast monsoon increases the suspended matter concentration and thus influences photosynthesis and causes the plankton POC production capacity to decrease. On the other hand, because of the large river discharge and abundant nutrient import [26,98], especially in the summer, the CDW occupies almost the whole surface ocean at $30^{\circ} \mathrm{N}$ in the ECS. Hence, under appropriate light and nutrient conditions, the CDW-influenced area and induced oceanic POC production are relatively high compared with the dry season. In addition, the impoundment in the wet season and drain in the dry season of the 
dam controlled by TGP leads to the seasonal difference decreases $[99,100]$. However, in the long term, the average POC concentration decreases continuously, following the sediment discharge trend instead of the diluted water discharge fluctuation, which implies that the POC variation in the Changjiang Estuary and adjacent ECS is mainly influenced by the riverine POC import through TGP reservoir affect sediment change.

\subsection{Ratio Variation}

As we discussed above, the total POC content decreases, while the ocean-produced POC increases. To determine the reason for this, the POC: $\mathrm{Chl}-a(\mathrm{C} / \mathrm{Chl}-a)$ and POC: PON $(\mathrm{C} / \mathrm{N})$ were investigated during the three TGP periods (Figures 10 and 11), where PON refers to detritus-N from our model results. The C/Chl- $a$ ratio is used to evaluate the POC characteristics of different sources. When C/Chl- $a$ ratio $>200$, the POC is mostly derived from the nonliving organic detritus pool, otherwise it mainly originates from phytoplankton production [101,102]. With respect to the $\mathrm{C} / \mathrm{N}$ ratio, terrestrial organic matter usually contains cellulose, which has a higher proportion than that in the ocean $[103,104]$. Therefore, a $\mathrm{C} / \mathrm{N}$ ratio $>12$ usually represents waters dominated by terrestrial sources, such as the Danube [105] and Changjiang rivers [106], while $\mathrm{C} / \mathrm{N}$ ratio $<8$ represents waters dominated by oceanic sources [72]. Figure 10 shows the carbon-rich region (overlapping of $C / N>12$ and C/Chl- $a>200$ ) in our research area, which is distributed along the direction of diluted water diffusion. The overlapping area near the estuary and coastal region implies that the potential source of POC is the terrestrial non-living organic detritus pool.

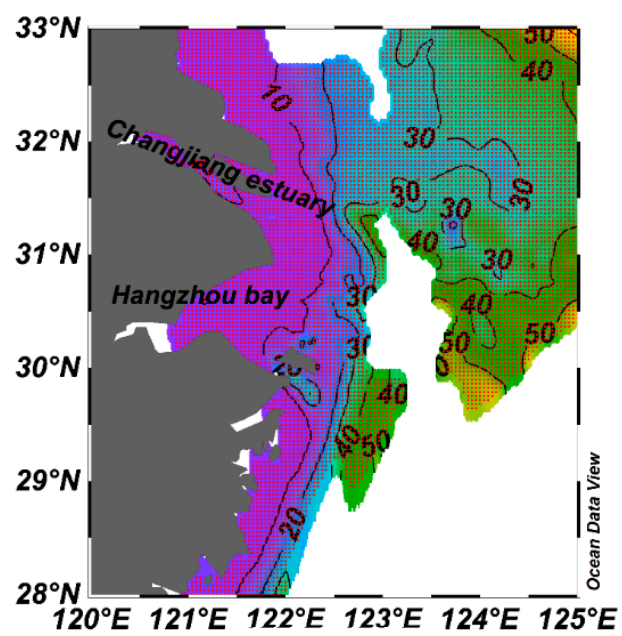

(a)

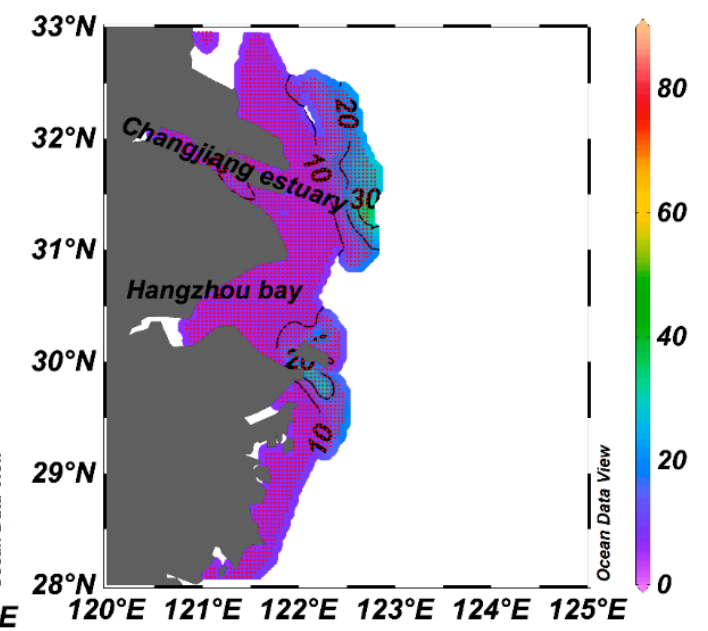

(b)

Figure 10. Distribution of the surface C/Chl- $a>200$ (a) and overlapping area of C/N > 12 and C/Chl- $a$ $>200$ (b) in the Changjiang Estuary and adjacent ECS. The contours represent the isobaths.

In our case, the ratios of $\mathrm{C} / \mathrm{Chl}-a$ and $\mathrm{C} / \mathrm{N}$ change with seasons and TGP periods (Figure 11). The range of C/Chl- $a$ is wide in summer (113.1-1645.8) and narrow in autumn (124.5-1215.7). In summer, the area with C/Chl- $a>200$ takes $80 \%$ of the research area, which means carbon-rich water from organic detritus pool is overwhelming. Winter and spring have similar patterns. C/Chl- $a$ ranges from 104.1 to 1873.9 in winter and 199.6 to 1143.0 in spring. The highest value appears in the maximum turbidity zone. The area with C/Chl- $a>200$ takes about $75 \%$ of the total area in spring, and remains at $80 \%$ in winter, which indicates the area dominated by biological POC production is larger in spring than in winter. As for the $\mathrm{C} / \mathrm{N}$ ratio, $\mathrm{C} / \mathrm{N}>12$ proportion decreases from $75 \%$ in summer to around $65 \%$ in autumn and spring, even less than $60 \%$ in winter, followed by the proportions of $\mathrm{C} / \mathrm{N}<8$ and $8<\mathrm{C} / \mathrm{N}$ $<12$ arise. 


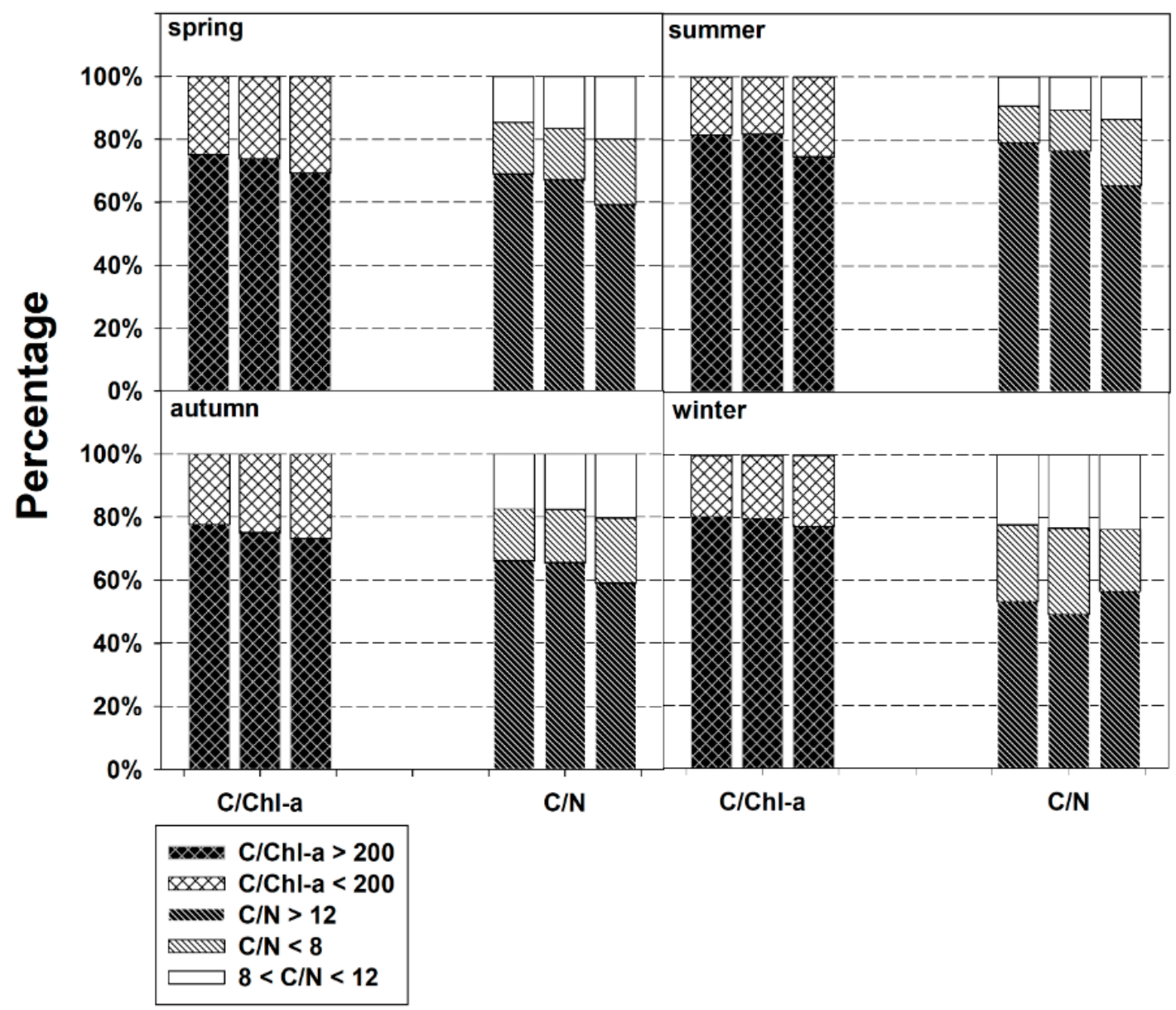

Figure 11. Percentages of areas with $\mathrm{C} / \mathrm{Chl}-a>200$ and $\mathrm{C} / \mathrm{Chl}-a<200$ and percentages of areas with $\mathrm{C} / \mathrm{N}$ $>12, \mathrm{C} / \mathrm{N}<8$, and $8<\mathrm{C} / \mathrm{N}<12$ in the coastal region of the ECS and Changjiang Estuary in different seasons. The areas with C/Chl- $a>200$ and C/Chl- $a<200$ are dominated by the non-living organic pool and living biological part, respectively; the area with $\mathrm{C} / \mathrm{N}>12$ indicates a terrestrial source, while areas with $\mathrm{C} / \mathrm{N}<8$ and $8<\mathrm{C} / \mathrm{N}<12$ represent oceanic and uncertain sources, respectively. From left to right, each group represents the ES-TGP, MS-TGP, and LS-TGP, respectively.

Our results demonstrate that the research area is strongly influenced by the CDW with a predominant C/Chl- $a>200$ area in the coastal ECS during all four seasons. The percentage of the area with C/Chl- $a>200$ decreases in spring because the reduced turbidity and increased nutrient concentration induce high-phytoplankton biomass [107], which matches the C/N ratio variation. In summer, as the phytoplankton biomass continues to increase, the nutrients are rapidly exhausted and strong water stratification prevents the nutrient supply from the bottom layer, while abundant water flux leads to the enrichment of the terrestrial organic matter input. Regarding the $\mathrm{C} / \mathrm{N}$ ratio, although the terrestrial input still thrives, the oceanic influence gradually strengthens with the progressing TGP project. In fact, except for winter, much of the increase occurs in areas with a $\mathrm{C} / \mathrm{N}$ ratio $<8$, especially in the LS-TGP mixing area when the sediment flux causes the reduction of the extent and area of the turbidity and phytoplankton photosynthesis and production are favored. In addition, the activity and increase in primary consumers, bacteria, and heterotrophs decomposing the POC can be influencing factors that lower the $\mathrm{C} / \mathrm{N}$ and $\mathrm{C} / \mathrm{Chl}-a$ ratios of the water column [102].

Previous studies demonstrated the effect of the three gorges dam on the retention of silicon [108,109]. This effect can change the phytoplankton community structure in the Changjiang Estuary and adjacent coastal ECS [21,110]. Although diatoms still dominate, the dinoflagellate proportion gradually increases, especially after TGP impoundment. Dinoflagellates have higher respiration rates than diatoms [111,112] and thus less POC is produced in the LS-TGP than in the ES-TGP. Therefore, although riverine POC 
still dominates, the oceanic POC production due to TGP regulation is non-negligible in the Changjiang Estuary and adjacent ECS.

\section{Conclusions}

In this paper, a 3D physical-biogeochemical model was built to evaluate the riverine input and ocean-produced POC in the Changjiang Estuary and adjacent ECS, as well as the seasonal and interannual variability during different TGP periods. The comparisons between the model results and observations, including satellite and in situ data, demonstrate the model's good performance in our research area. Historical observations and studies revealed that TGP regulates the river flux into the ECS, with a light but stable decrease, except for the LS-TGP, during which the sediment discharge presents a dramatical decrease of $\sim 55 \%$ compared with the ES-TGP.

Based on the input conditions from different periods, the modeled salinity distribution reveals that the area influenced by diluted water decreases in the wet season and expands in the dry season. Correspondingly, the POC pattern changes, that is, the high-POC area $\left(>40 \mu \mathrm{mol} \mathrm{L}{ }^{-1}\right)$ decreases from $7468 \mathrm{~km}^{2}$ in the ES-TGP to $5936 \mathrm{~km}^{2}$ in the LS-TGP in spring. The POC and its related variables were analyzed in the whole water column. The results show that the average POC decreases from 19.5 to $17.8 \mu \mathrm{mol} \mathrm{L}-1$, Chl- $a$ increases from 1.40 to $1.86 \mu \mathrm{mol} \mathrm{L}-1, \mathrm{NO}_{3}$ increases from 19.2 to $20.3 \mu \mathrm{mol} \mathrm{L}-1$, and $\mathrm{PO}_{4}$ increases from 0.81 to $0.92 \mu \mathrm{mol} \mathrm{L}{ }^{-1}$, respectively, from ES-TGP to LS-TGP. The POC does not coincide with the trend of relevant variables, which implies that the biological activity should not be the dominant effect.

To quantify the influence of different POC sources, a three end-member mixing model was used. The model results show that the CDW dominates POC sources in summer, while offshore bottom water dominates in winter. In the meantime, the offshore surface water is an important replenishment source of the whole water mass. The corresponding biological POC was estimated by the results for different end-members. The results indicate strong activity in the estuary and coastal area, which is closely related to the decrease in the sediment discharge from ES-TGP to LS-TGP. The C/Chl- $a$ and $\mathrm{C} / \mathrm{N}$ ratios were used to discuss and testify the increase in oceanic biological POC during the three TGP periods. Our results show that the organic detritus and terrestrial input sources dominate in the Changjiang Estuary and adjacent coastal ECS, but their proportions gradually decrease because TGP induces the decrease in the sediment discharge and thus the CDW influence weakens, especially in the impoundment period of the LS-TGP. In a word, TGP affects the variabilities of the POC and relevant factors and thus significantly influences the ecosystem around the Changjiang Estuary and adjacent coastal ECS. Our study provides a good reference for the ecological studies in other similar coastal areas around the world that are influenced by dams from upstream rivers.

Author Contributions: Conceptualization, D.C.; methodology, D.C., Q.L., J.X. and K.W.; software, D.C.; investigation, D.C.; writing-original draft preparation, D.C.; writing-review and editing, D.C., Q.L., J.X. and K.W.; supervision, D.C.

Funding: This research was funded by National Natural Science Foundation of China (Grant No. 91328203), National Program on Key Basic Research Project of China (973 Program, Grant No. 2012CB956004), and Sun Yat-sen University Supercomputing Funding (Grant No. 42000-52603700).

Acknowledgments: The authors wish to thank Fei Chai, Feng Zhou and Peng Xiu provide essential information, and appreciate Kedong Yin for discussion and comments. Lastly, we acknowledge JCOPE reanalysis data provided by Application Laboratory, JAMSTEC and NASA for providing the MODIS data.

Conflicts of Interest: The authors declare no conflict of interest. 


\section{References}

1. Nelson, D.; Sommers, L.E. Total carbon, organic carbon, and organic matter 1. In Methods of Soil Analysis, Part 2. Chemical and Microbiological Properties; American Society of Agronomy: Madison, WI, USA, 1982; pp. 539-579.

2. Jahnke, R.A. The global ocean flux of particulate organic carbon: Areal distribution and magnitude. Glob. Biogeochem. Cycles 1996, 10, 71-88. [CrossRef]

3. Suess, E. Particulate organic carbon flux in the oceans-Surface productivity and oxygen utilization. Nature 1980, 288, 260. [CrossRef]

4. Armstrong, R.A.; Lee, C.; Hedges, J.I.; Honjo, S.; Wakeham, S.G. A new, mechanistic model for organic carbon fluxes in the ocean based on the quantitative association of POC with ballast minerals. Deep Sea Res. Part II Top. Stud. Oceanogr. 2001, 49, 219-236. [CrossRef]

5. Lutz, M.J.; Caldeira, K.; Dunbar, R.B.; Behrenfeld, M.J. Seasonal rhythms of net primary production and particulate organic carbon flux to depth describe the efficiency of biological pump in the global ocean. J. Geophys. Res. Ocean. 2007, 112. [CrossRef]

6. Turner, J.T. Zooplankton fecal pellets, marine snow, phytodetritus and the ocean's biological pump. Prog. Oceanogr. 2015, 130, 205-248. [CrossRef]

7. Schlünz, B.; Schneider, R. Transport of terrestrial organic carbon to the oceans by rivers: Re-estimating flux-and burial rates. Int. J. Earth Sci. 2000, 88, 599-606. [CrossRef]

8. Spilling, K.; Kremp, A.; Klais, R.; Olli, K.; Tamminen, T. Spring bloom community change modifies carbon pathways and C: N: P: Chl a stoichiometry of coastal material fluxes. Biogeosciences 2014, 11, 7275-7289. [CrossRef]

9. Sarà, G.; Leonardi, M.; Mazzola, A. Spatial and temporal changes of suspended matter in relation to wind and vegetation cover in a Mediterranean shallow coastal environment. Chem. Ecol. 1999, 16, 151-173. [CrossRef]

10. Haskell, W.Z., II; Kadko, D.; Hammond, D.E.; Knapp, A.N.; Prokopenko, M.G.; Berelson, W.M.; Capone, D.G. Upwelling velocity and eddy diffusivity from 7Be measurements used to compare vertical nutrient flux to export POC flux in the Eastern Tropical South Pacific. Mar. Chem. 2015, 168, 140-150. [CrossRef]

11. Hill, J.; Wheeler, P. Organic carbon and nitrogen in the northern California current system: Comparison of offshore, river plume, and coastally upwelled waters. Prog. Oceanogr. 2002, 53, 369-387. [CrossRef]

12. Gao, L.; Li, D.; Zhang, Y. Nutrients and particulate organic matter discharged by the Changjiang (Yangtze River): Seasonal variations and temporal trends. J. Geophys. Res. Biogeosci 2012, 117. [CrossRef]

13. Grossmann, M.M.; Gallager, S.M.; Mitarai, S. Continuous monitoring of near-bottom mesoplankton communities in the East China Sea during a series of typhoons. J. Oceanogr. 2015, 71, 115-124. [CrossRef]

14. Vidon, P.; Karwan, D.L.; Andres, A.S.; Inamdar, S.; Kaushal, S.; Morrison, J.; Mullaney, J.; Ross, D.S.; Schroth, A.W.; Shanley, J.B. In the path of the Hurricane: Impact of Hurricane Irene and Tropical Storm Lee on watershed hydrology and biogeochemistry from North Carolina to Maine, USA. Biogeochemistry 2018, 141, 351-364. [CrossRef]

15. Shih, Y.-Y.; Jin-Sheng, H.; Gong, G.-C.; Chin-Chang, H.; Wen-Chen, C.; Ming-An, L.; Kuo-Shu, C.; Meng-Hsien, C.; Chau-Ron, W. Field observations of changes in SST, chlorophyll and POC flux in the southern East China Sea before and after the passage of Typhoon Jangmi. TAO Terr. Atmos. Ocean. Sci. 2013, 24, 899. [CrossRef]

16. Chen, D.; He, L.; Liu, F.; Yin, K. Effects of typhoon events on chlorophyll and carbon fixation in different regions of the East China Sea. Estuar. Coast. Shelf Sci. 2017, 194, 229-239. [CrossRef]

17. Yang, Z.-S.; Wang, H.-J.; Saito, Y.; Milliman, J.; Xu, K.; Qiao, S.; Shi, G. Dam impacts on the Changjiang (Yangtze) River sediment discharge to the sea: The past 55 years and after the Three Gorges Dam. Water Resour. Res. 2006, 42. [CrossRef]

18. Dai, Z.; Du, J.; Li, J.; Li, W.; Chen, J. Runoff characteristics of the Changjiang River during 2006: Effect of extreme drought and the impounding of the Three Gorges Dam. Geophys. Res. Lett. 2008, 35. [CrossRef]

19. Liu, W. Study on particulate organic carbon in the East China Sea. Oceanol. Limnol. Sin. 1997, 28, 39-43.

20. Chen, C.T.A. The Three Gorges Dam: Reducing the upwelling and thus productivity in the East China Sea. Geophys. Res. Lett. 2000, 27, 381-383. [CrossRef] 
21. Jiao, N.; Zhang, Y.; Zeng, Y.; Gardner, W.D.; Mishonov, A.V.; Richardson, M.J.; Hong, N.; Pan, D.; Yan, X.-H.; Jo, Y.-H. Ecological anomalies in the East China Sea: Impacts of the three gorges dam? Water Res. 2007, 41, 1287-1293. [CrossRef] [PubMed]

22. Chen, X.; Yan, Y.; Fu, R.; Dou, X.; Zhang, E. Sediment transport from the Yangtze River, China, into the sea over the Post-Three Gorge Dam Period: A discussion. Quat. Int. 2008, 186, 55-64. [CrossRef]

23. Dai, Z.; Du, J.; Zhang, X.; Su, N.; Li, J. Variation of riverine material loads and environmental consequences on the Changjiang (Yangtze) Estuary in recent decades (1955-2008). Environ. Sci. Technol. 2010, 45, 223-227. [CrossRef] [PubMed]

24. Yang, S.; Milliman, J.; Li, P.; Xu, K. 50,000 dams later: Erosion of the Yangtze River and its delta. Glob. Planet. Chang. 2011, 75, 14-20. [CrossRef]

25. $\mathrm{Xu}, \mathrm{K} . ;$ Milliman, J.D. Seasonal variations of sediment discharge from the Yangtze River before and after impoundment of the Three Gorges Dam. Geomorphology 2009, 104, 276-283. [CrossRef]

26. Tang, Q.; Bao, Y.; He, X.; Fu, B.; Collins, A.L.; Zhang, X. Flow regulation manipulates contemporary seasonal sedimentary dynamics in the reservoir fluctuation zone of the Three Gorges Reservoir, China. Sci. Total Environ. 2016, 548, 410-420. [CrossRef] [PubMed]

27. Chen, C.T.A.; Wang, S.L. Carbon, alkalinity and nutrient budgets on the East China Sea continental shelf. J. Geophys. Res. Ocean. 1999, 104, 20675-20686. [CrossRef]

28. Zhou, F.; Chai, F.; Huang, D.; Xue, H.; Chen, J.; Xiu, P.; Xuan, J.; Li, J.; Zeng, D.; Ni, X. Investigation of hypoxia off the Changjiang Estuary using a coupled model of ROMS-CoSiNE. Prog. Oceanogr. 2017, 159, 237-254. [CrossRef]

29. Luo, X.; Wei, H.; Liu, Z.; Zhao, L. Seasonal variability of air-sea $\mathrm{CO}_{2}$ fluxes in the Yellow and East China Seas: A case study of continental shelf sea carbon cycle model. Cont. Shelf Res. 2015, 107, 69-78. [CrossRef]

30. Watanabe, K.; Kuwae, T. How organic carbon derived from multiple sources contributes to carbon sequestration processes in a shallow coastal system? Glob. Chang. Biol. 2015, 21, 2612-2623.

31. Yamaguchi, H.; Kim, H.-C.; Son, Y.B.; Kim, S.W.; Okamura, K.; Kiyomoto, Y.; Ishizaka, J. Seasonal and summer interannual variations of SeaWiFS chlorophyll a in the Yellow Sea and East China Sea. Prog. Oceanogr. 2012, 105, 22-29. [CrossRef]

32. Chai, F.; Dugdale, R.; Peng, T.-H.; Wilkerson, F.; Barber, R. One-dimensional ecosystem model of the equatorial Pacific upwelling system. Part I: Model development and silicon and nitrogen cycle. Deep Sea Res. Part II Top. Stud. Oceanogr. 2002, 49, 2713-2745. [CrossRef]

33. Ezcurra, E.; Barrios, E.; Ezcurra, P.; Ezcurra, A.; Vanderplank, S.; Vidal, O.; Villanueva-Almanza, L.; Aburto-Oropeza, O. A natural experiment reveals the impact of hydroelectric dams on the estuaries of tropical rivers. Sci. Adv. 2019, 5, 9875. [CrossRef] [PubMed]

34. Moore, A.M.; Arango, H.G.; Di Lorenzo, E.; Cornuelle, B.D.; Miller, A.J.; Neilson, D.J. A comprehensive ocean prediction and analysis system based on the tangent linear and adjoint of a regional ocean model. Ocean Model. 2004, 7, 227-258. [CrossRef]

35. Shchepetkin, A.F.; McWilliams, J.C. The regional oceanic modeling system (ROMS): A split-explicit, free-surface, topography-following-coordinate oceanic model. Ocean Model. 2005, 9, 347-404. [CrossRef]

36. Peliz, Á.; Dubert, J.; Haidvogel, D.B.; Le Cann, B. Generation and unstable evolution of a density-driven eastern poleward current: The Iberian Poleward Current. J. Geophys. Res. Ocean. 2003, 108. [CrossRef]

37. Smith, R.N.; Chao, Y.; Li, P.P.; Caron, D.A.; Jones, B.H.; Sukhatme, G.S. Planning and implementing trajectories for autonomous underwater vehicles to track evolving ocean processes based on predictions from a regional ocean model. Int. J. Robot. Res. 2010, 29, 1475-1497. [CrossRef]

38. Liu, Q.; Rothstein, L.M.; Luo, Y. Dynamics of the Block Island Sound estuarine plume. J. Phys. Oceanogr. 2016, 46, 1633-1656. [CrossRef]

39. Liu, Q.; Rothstein, L.M.; Luo, Y. A periodic freshwater patch detachment process from the Block Island S ound estuarine plume. J. Geophys. Res. Ocean. 2017, 122, 570-586. [CrossRef]

40. Zhou, F.; Xue, H.; Huang, D.; Xuan, J.; Ni, X.; Xiu, P.; Hao, Q. Cross-shelf exchange in the shelf of the East China Sea. J. Geophys. Res. Ocean. 2015, 120, 1545-1572. [CrossRef]

41. Egbert, G.D.; Erofeeva, S.Y. Efficient inverse modeling of barotropic ocean tides. J. Atmos. Ocean. Technol. 2002, 19, 183-204. [CrossRef]

42. Yangtze Statistical Yearbook 1994-2008; Yangtze River Statistical Publishing House: Wuhan, China, 2008. 
43. Chang, P.H.; Isobe, A. A numerical study on the Changjiang diluted water in the Yellow and East China Seas. J. Geophys. Res. Ocean. 2003, 108. [CrossRef]

44. Large, W.; Pond, S. Open ocean momentum flux measurements in moderate to strong winds. J. Phys. Oceanogr. 1981, 11, 324-336. [CrossRef]

45. Kalnay, E.; Kanamitsu, M.; Kistler, R.; Collins, W.; Deaven, D.; Gandin, L.; Iredell, M.; Saha, S.; White, G.; Woollen, J. The NCEP/NCAR 40-year reanalysis project. Bull. Am. Meteorol. Soc. 1996, 77, 437-472. [CrossRef]

46. Zhang, H.M.; Bates, J.J.; Reynolds, R.W. Assessment of composite global sampling: Sea surface wind speed. Geophys. Res. Lett. 2006, 33. [CrossRef]

47. Liu, Q.; Chai, F.; Dugdale, R.; Chao, Y.; Xue, H.; Rao, S.; Wilkerson, F.; Farrara, J.; Zhang, H.; Wang, Z. San Francisco Bay nutrients and plankton dynamics as simulated by a coupled hydrodynamic-ecosystem model. Cont. Shelf Res. 2018, 161, 29-48. [CrossRef]

48. Chavez, F.P.; Buck, K.R.; Coale, K.; Martin, J.; DiTullio, G.; Welschmeyer, N.; Jacobson, A.C.; Barber, R.T. Growth rates, grazing, sinking, and iron limitation of equatorial Pacific phytoplankton. Limnol. Oceanogr. 1991, 36, 1816-1833. [CrossRef]

49. Landry, M.R.; Constantinou, J.; Kirshtein, J. Microzooplankton grazing in the central equatorial Pacific during February and August, 1992. Deep Sea Res. Part II Top. Stud. Oceanogr. 1995, 42, 657-671. [CrossRef]

50. Coale, K.H.; Johnson, K.S.; Fitzwater, S.E.; Gordon, R.M.; Tanner, S.; Chavez, F.P.; Ferioli, L.; Sakamoto, C.; Rogers, P.; Millero, F. A massive phytoplankton bloom induced by an ecosystem-scale iron fertilization experiment in the equatorial Pacific Ocean. Nature 1996, 383, 495. [CrossRef] [PubMed]

51. Frost, B.; Franzen, N. Grazing and iron limitation in the control of phytoplankton stock and nutrient concentration: A chemostat analogue of the Pacific equatorial upwelling zone. Mar. Ecol. Prog. Ser. Oldend. 1992, 83, 291-303. [CrossRef]

52. Anderson, L.A.; Sarmiento, J.L. Redfield ratios of remineralization determined by nutrient data analysis. Glob. Biogeochem. Cycles 1994, 8, 65-80. [CrossRef]

53. Redfeild, A. The influence of organisms on the composition of sea water. Sea 1963, 2, 26-77.

54. Xiu, P.; Chai, F. Spatial and temporal variability in phytoplankton carbon, chlorophyll, and nitrogen in the North Pacific. J. Geophys. Res. Ocean. 2012, 117. [CrossRef]

55. Ludwig, W.; Probst, J.L.; Kempe, S. Predicting the oceanic input of organic carbon by continental erosion. Glob. Biogeochem. Cycles 1996, 10, 23-41. [CrossRef]

56. River Sediment Bulletin of China 1994-2008; China Water \& Power Press: Beijing, China, 2008.

57. Xiu, P.; Chai, F. Modeled biogeochemical responses to mesoscale eddies in the South China Sea. J. Geophys. Res. Ocean. 2011, 116. [CrossRef]

58. Isobe, A.; Guo, X.; Takeoka, H. Hindcast and predictability of sporadic Kuroshio-water intrusion (kyucho in the Bungo Channel) into the shelf and coastal waters. J. Geophys. Res. Ocean. 2010, 115. [CrossRef]

59. Kunoki, S.; Manda, A.; Kodama, Y.; Iizuka, S.; Sato, K.; Fathrio, I.; Mitsui, T.; Seko, H.; Moteki, Q.; Minobe, S. Oceanic influence on the Baiu frontal zone in the East China Sea. J. Geophys. Res. 2015, 120, 449-463. [CrossRef]

60. Iseki, K.; Okamura, K.; Kiyomoto, Y. Seasonality and composition of downward particulate fluxes at the continental shelf and Okinawa Trough in the East China Sea. Deep Sea Res. Part II Top. Stud. Oceanogr. 2003, 50, 457-473. [CrossRef]

61. Zhao, J.-S.; Ji, H.-W.; Guo, Z.-G. The vertical distribution of particulate organic carbon in the typical areas of the East China Sea in winter. Mar. Sci. Qingdao Chin. Ed. 2003, 27, 59-63.

62. Zhu, Z.Y.; Zhang, J.; Wu, Y.; Lin, J. Bulk particulate organic carbon in the East China Sea: Tidal influence and bottom transport. Prog. Oceanogr. 2006, 69, 37-60. [CrossRef]

63. Song, X.-H.; Shi, X.-F.; Cai, D.-L.; Wang, G.-Q.; Wang, J.-T. Distributions of TSM, POC and PN in the Changjiang Estuary area in autumn after the river closure at Three Gorges. Adv. Mar. Sci. 2007, $25,168$.

64. Shi, X.; Zhang, T.; Zhang, C.; Cheng, J. Spatial and temporal distribution of particulate organic carbon in Yellow Sea and East China Sea. Mar. Environ. Sci. 2011, 1, 25-29.

65. Hung, C.-C.; Tseng, C.-W.; Gong, G.-C.; Chen, K.-S.; Chen, M.-H.; Hsu, S.-C. Fluxes of particulate organic carbon in the East China Sea in summer. Biogeosciences 2013, 10, 6469-6484. [CrossRef]

66. Pan, J.W.; Zhu, J. Scientific Verification is the Basis for Correct Decision-making of Major Project-Practical Proof on Verification Conclusions of TGP. Eng. Sci. 2001, 3, 21-26. 
67. Jiazhu, W. Three Gorges Project: The largest water conservancy project in the world. Public Adm. Dev. Int. J. Manag. Res. Pract. 2002, 22, 369-375. [CrossRef]

68. Lau, K.; Weng, H. Coherent modes of global SST and summer rainfall over China: An assessment of the regional impacts of the 1997-1998 El Nino. J. Clim. 2001, 14, 1294-1308. [CrossRef]

69. Dai, Z.; Fagherazzi, S.; Mei, X.; Gao, J. Decline in suspended sediment concentration delivered by the Changjiang (Yangtze) River into the East China Sea between 1956 and 2013. Geomorphology 2016, 268, 123-132. [CrossRef]

70. Dai, Z.; Liu, J.T. Impacts of large dams on downstream fluvial sedimentation: An example of the Three Gorges Dam (TGD) on the Changjiang (Yangtze River). J. Hydrol. 2013, 480, 10-18. [CrossRef]

71. Zhang, W.; Xu, Y.; Wang, Y.; Peng, H. Modeling sediment transport and river bed evolution in river system. J. Clean Energy Technol. 2014, 2, 175-179. [CrossRef]

72. Milliman, J.D.; Qinchun, X.; Zuosheng, Y. Transfer of particulate organic carbon and nitrogen from the Yangtze River to the ocean. Am. J. Sci. 1984, 284, 824-834. [CrossRef]

73. Gao, X.; Song, J. Phytoplankton distributions and their relationship with the environment in the Changjiang Estuary, China. Mar. Pollut. Bull. 2005, 50, 327-335. [CrossRef]

74. Shi, J.Z.; Zhang, S.; Hamilton, L. Bottom fine sediment boundary layer and transport processes at the mouth of the Changjiang Estuary, China. J. Hydrol. 2006, 327, 276-288. [CrossRef]

75. Li, D.; Zhang, J.; Huang, D.; Wu, Y.; Liang, J. Oxygen depletion off the Changjiang (Yangtze River) estuary. Sci. China Ser. D Earth Sci. 2002, 45, 1137-1146. [CrossRef]

76. Chen, C.; Xue, P.; Ding, P.; Beardsley, R.C.; Xu, Q.; Mao, X.; Gao, G.; Qi, J.; Li, C.; Lin, H. Physical mechanisms for the offshore detachment of the Changjiang Diluted Water in the East China Sea. J. Geophys. Res. Ocean. 2008, 113. [CrossRef]

77. Zhu, J.; Zhu, Z.; Lin, J.; Wu, H.; Zhang, J. Distribution of hypoxia and pycnocline off the Changjiang Estuary, China. J. Mar. Syst. 2016, 154, 28-40. [CrossRef]

78. Gao, X.; Song, J. Main geochemical characteristics and key biogeochemical carbon processes in the East China Sea. J. Coast. Res. 2006, 22, 1330-1339. [CrossRef]

79. Hung, C.-C.; Gong, G.-C.; Chiang, K.-P.; Chen, H.-Y.; Yeager, K.M. Particulate carbohydrates and uronic acids in the northern East China Sea. Estuar. Coast. Shelf Sci. 2009, 84, 565-572. [CrossRef]

80. Van Mooy, B.A.; Fredricks, H.F.; Pedler, B.E.; Dyhrman, S.T.; Karl, D.M.; Koblížek, M.; Lomas, M.W.; Mincer, T.J.; Moore, L.R.; Moutin, T. Phytoplankton in the ocean use non-phosphorus lipids in response to phosphorus scarcity. Nature 2009, 458, 69. [CrossRef]

81. Hu, J.; Yang, S.-F.; Wang, X.-K. Sedimentation in Yangtze River above Three Gorges Project since 2003. J. Sediment. Res. 2013, 1, 39-40.

82. Yang, S.; Belkin, I.; Belkina, A.; Zhao, Q.; Zhu, J.; Ding, P. Delta response to decline in sediment supply from the Yangtze River: Evidence of the recent four decades and expectations for the next half-century. Estuar. Coast. Sci. 2003, 57, 689-699. [CrossRef]

83. Li, P.; Yang, S.; Milliman, J.; Xu, K.; Qin, W.; Wu, C.; Chen, Y.; Shi, B. Spatial, temporal, and human-induced variations in suspended sediment concentration in the surface waters of the Yangtze Estuary and adjacent coastal areas. Estuaries Coasts 2012, 35, 1316-1327. [CrossRef]

84. Luo, X.; Yang, S.; Zhang, J. The impact of the Three Gorges Dam on the downstream distribution and texture of sediments along the middle and lower Yangtze River (Changjiang) and its estuary, and subsequent sediment dispersal in the East China Sea. Geomorphology 2012, 179, 126-140. [CrossRef]

85. Keeling, R.F.; Peng, T.-H. Transport of heat, $\mathrm{CO}_{2}$ and $\mathrm{O}_{2}$ by the Atlantic's thermohaline circulation. Philos. Trans. R. Soc. Lond. Ser. B Biol. Sci. 1995, 348, 133-142.

86. Han, A.; Dai, M.; Kao, S.-J.; Gan, J.; Li, Q.; Wang, L.; Zhai, W.; Wang, L. Nutrient dynamics and biological consumption in a large continental shelf system under the influence of both a river plume and coastal upwelling. Limnol. Oceanogr. 2012, 57, 486-502. [CrossRef]

87. Wang, K.; Chen, J.; Jin, H.; Li, H.; Gao, S.; Xu, J.; Lu, Y.; Huang, D.; Hao, Q.; Weng, H. Summer nutrient dynamics and biological carbon uptake rate in the Changjiang River plume inferred using a three end-member mixing model. Cont. Shelf Res. 2014, 91, 192-200. [CrossRef]

88. Li, D.; Yao, P.; Bianchi, T.S.; Zhang, T.; Zhao, B.; Pan, H.; Wang, J.; Yu, Z. Organic carbon cycling in sediments of the Changjiang Estuary and adjacent shelf: Implication for the influence of Three Gorges Dam. J. Mar. Syst. 2014, 139, 409-419. [CrossRef] 
89. Dickson, B.; Yashayaev, I.; Meincke, J.; Turrell, B.; Dye, S.; Holfort, J. Rapid freshening of the deep North Atlantic Ocean over the past four decades. Nature 2002, 416, 832. [CrossRef] [PubMed]

90. Yu-song, S.; Xue-chuan, W. Water masses in China seas. In Oceanology of China Seas; Springer: Berlin, Germany, 1994; pp. 3-16.

91. Wei, H.; He, Y.; Li, Q.; Liu, Z.; Wang, H. Summer hypoxia adjacent to the Changjiang Estuary. J. Mar. Syst. 2007, 67, 292-303. [CrossRef]

92. Beardsley, R.; Limeburner, R.; Yu, H.; Cannon, G. Discharge of the Changjiang (Yangtze river) into the East China sea. Cont. Shelf Res. 1985, 4, 57-76. [CrossRef]

93. Zhai, W.D.; Chen, J.F.; Jin, H.Y.; Li, H.L.; Liu, J.W.; He, X.Q.; Bai, Y. Spring carbonate chemistry dynamics of surface waters in the northern East China Sea: Water mixing, biological uptake of $\mathrm{CO}_{2}$, and chemical buffering capacity. J. Geophys. Res. Ocean. 2014, 119, 5638-5653. [CrossRef]

94. Li, P.; Shi, B.; Wang, Y.; Qin, W.; Li, Y.; Chen, J. Analysis of the characteristics of offshore currents in the Changjiang (Yangtze River) estuarine waters based on buoy observations. Acta Oceanol. Sin. 2017, 36, 13-20. [CrossRef]

95. Zhang, J.; Liu, S.; Ren, J.; Wu, Y.; Zhang, G. Nutrient gradients from the eutrophic Changjiang (Yangtze River) Estuary to the oligotrophic Kuroshio waters and re-evaluation of budgets for the East China Sea Shelf. Prog. Oceanogr. 2007, 74, 449-478. [CrossRef]

96. Omand, M.M.; D'Asaro, E.A.; Lee, C.M.; Perry, M.J.; Briggs, N.; Cetinić, I.; Mahadevan, A. Eddy-driven subduction exports particulate organic carbon from the spring bloom. Science 2015, 348, 222-225. [CrossRef] [PubMed]

97. Lian, E.; Yang, S.; Wu, H.; Yang, C.; Li, C.; Liu, J.T. Kuroshio subsurface water feeds the wintertime Taiwan Warm Current on the inner East China Sea shelf. J. Geophys. Res. Ocean. 2016, 121, 4790-4803. [CrossRef]

98. Wu, H.; Zhu, J.; Shen, J.; Wang, H. Tidal modulation on the Changjiang River plume in summer. J. Geophys. Res. Ocean. 2011, 116. [CrossRef]

99. Li, M.; Xu, K.; Watanabe, M.; Chen, Z. Long-term variations in dissolved silicate, nitrogen, and phosphorus flux from the Yangtze River into the East China Sea and impacts on estuarine ecosystem. Estuar. Coast. Shelf Sci. 2007, 71, 3-12. [CrossRef]

100. Guo, H.; Hu, Q.; Zhang, Q.; Feng, S. Effects of the three gorges dam on Yangtze river flow and river interaction with Poyang Lake, China: 2003-2008. J. Hydrol. 2012, 416, 19-27. [CrossRef]

101. Trefry, J.H.; Metz, S.; Nelsen, T.A.; Trocine, R.P.; Eadie, B.J. Transport of particulate organic carbon by the Mississippi River and its fate in the Gulf of Mexico. Estuaries 1994, 17, 839. [CrossRef]

102. Liénart, C.; Susperregui, N.; Rouaud, V.; Cavalheiro, J.; David, V.; Del Amo, Y.; Duran, R.; Lauga, B.; Monperrus, M.; Pigot, T. Dynamics of particulate organic matter in a coastal system characterized by the occurrence of marine mucilage-A stable isotope study. J. Sea Res. 2016, 116, 12-22. [CrossRef]

103. Hedges, J.; Keil, R.; Benner, R. What happens to terrestrial organic matter in the ocean? Org. Geochem. 1997, 27, 195-212. [CrossRef]

104. Cai, W. Estuarine and Coastal Ocean Carbon Paradox: $\mathrm{CO}_{2}$ Sinks or Sites of Terrestrial Carbon Incineration? Annu. Rev. Mar. Sci. 2011, 3, 123-145. [CrossRef]

105. Saliot, A.; Parrish, C.C.; Sadouni, N.m.; Bouloubassi, I.; Fillaux, J.; Cauwet, G. Transport and fate of Danube Delta terrestrial organic matter in the Northwest Black Sea mixing zone. Mar. Chem. 2002, 79, $243-259$. [CrossRef]

106. Gao, J.; Wang, Y.; Pan, S.; Zhang, R.; Li, J.; Bai, F. Spatial distributions of organic carbon and nitrogen and their isotopic compositions in sediments of the Changjiang Estuary and its adjacent sea area. J. Geogr. Sci. 2008, 18, 46-58. [CrossRef]

107. Zhu, Z.-Y.; Ng, W.-M.; Liu, S.-M.; Zhang, J.; Chen, J.-C.; Wu, Y. Estuarine phytoplankton dynamics and shift of limiting factors: A study in the Changiiang (Yangtze River) Estuary and adjacent area. Estuar. Coast. Shelf Sci. 2009, 84, 393-401. [CrossRef]

108. Ding, T.; Wan, D.; Wang, C.; Zhang, F. Silicon isotope compositions of dissolved silicon and suspended matter in the Yangtze River, China. Geochim. Cosmochim. Acta 2004, 68, 205-216. [CrossRef]

109. Ma, N.; Li, Z.; Xia, S.; Zhu, Z.; Song, Z. Retention effects of river damming on dissolved silicon. Inland Waters 2018, 8, 207-215. [CrossRef] 
110. Jiang, Z.; Liu, J.; Chen, J.; Chen, Q.; Yan, X.; Xuan, J.; Zeng, J. Responses of summer phytoplankton community to drastic environmental changes in the Changjiang (Yangtze River) estuary during the past 50 years. Water Res. 2014, 54, 1-11. [CrossRef]

111. Burkhardt, S.; Riebesell, U.; Zondervan, I. Effects of growth rate, $\mathrm{CO}_{2}$ concentration, and cell size on the stable carbon isotope fractionation in marine phytoplankton. Geochim. Cosmochim. Acta 1999, 63, 3729-3741. [CrossRef]

112. Menden-Deuer, S.; Lessard, E.J. Carbon to volume relationships for dinoflagellates, diatoms, and other protist plankton. Limnol. Oceanogr. 2000, 45, 569-579. [CrossRef]

(C) 2019 by the authors. Licensee MDPI, Basel, Switzerland. This article is an open access article distributed under the terms and conditions of the Creative Commons Attribution (CC BY) license (http://creativecommons.org/licenses/by/4.0/). 